$$
\begin{gathered}
-46 \\
v 93-176938
\end{gathered}
$$

\title{
PALINSPASTIC RECONSTRUCTION OF SOUTHEASTERN CALIFORNIA AND SOUTHWESTERN ARIZONA FOR THE MIDDLE MIOCENE
}

\author{
Stephen M. Richard
}

Institute for Crustal Studies

University of California

Santa Barbara, California 93106-1100

Present address:

Arizona Geological Survey

845 N. Park

Tucson, AZ 85719

tel: 602-882-4795

FAX: 602-628-5106

Submitted to Tectonics 6/21/91

Reviewed manuscript received 2/92

Revised 10/20/92 


\begin{abstract}
A paleogeographic reconstruction of southeastern California and southwestern Arizona at $10 \mathrm{Ma}$ has been made based on available geologic and geophysical data. Clockwise rotation of $39^{\circ}$ has been reconstructed in the eastern Transverse Ranges, consistent with paleomagnetic data from late Miocene volcanic rocks, and with slip estimates for left-lateral faults within the eastern Transverse Ranges and NW-trending right lateral faults in the Mojave Desert. This domain of rotated rocks is bounded by the Pinto Mountain fault on the north. In the absence of evidence for rotation of the San Bernardino Mountains or for significant right slip faults within the San Bernardino Mountains, the model requires that the late Miocene Pinto Mountain fault become a thrust fault gaining displacement to the west. The Squaw Peak thrust system of Meisling and Weldon [1989] may be a western continuation of this fault system. The Sheep Hole fault bounds the rotating domain on the east. East of this fault an array of NW-trending right slip faults and south-trending extensional transfer zones has produced a basin and range physiography while accumulating up to $14 \mathrm{~km}$ of right slip. This maximum is significantly less than the $37.5 \mathrm{~km}$ of right slip required in this region by a recent reconstruction of the central Mojave Desert [Dokka and Travis, 1990a]. Geologic relations along the southern boundary of the rotating domain are poorly know, but this boundary is interpreted to involve a series of curved strike slip faults and non-coaxial extension, bounded on the southeast by the Mammoth Wash and related faults in the eastern Chocolate Mountains. Available constraints on timing suggest that Quaternary movement on the Pinto Mountain and nearby faults is unrelated to the rotation of the eastern Transverse Ranges, and was preceded by a hiatus during part of Pliocene time which followed the deformation producing the rotation. The reconstructed Clemens Well fault in the Orocopia Mountains, proposed as a major early Miocene strand of the San Andreas fault, projects eastward towards Arizona, where early Miocene rocks and structures are continuous across its trace. The model predicts a $14^{\circ}$ clockwise rotation and $55 \mathrm{~km}$ extension along the present trace of the San Andreas fault during late Miocene and early Pliocene time. Palinspastic reconstructions of the San Andreas system based on this proposed reconstruction may be significantly modified from current models.
\end{abstract}




\section{INTRODUCTION}

The interaction of extension and vertical-axis rotation in a large-scale, distributed strike-slip fault system dominates the Neogene geologic history of southern California [Luyendyk, 1989]. The plate tectonic framework for the evolution of western North America [Atwater, 1970, 1988] predicts $1360 \pm 90 \mathrm{~km}$ of right slip between the Pacific and North American plates since $30 \mathrm{Ma}$ [Stock and Molnar, 1988]. In view of the absence of geologic evidence for significant transform motion within the continent before about $20 \mathrm{Ma}$ [Powell and Weldon, 1992], a large part of this slip must be accommodated by poorly documented offshore faults [Sedlock and Hamilton, 1991]. Since inception of the San Andreas Fault system between 20 and $18 \mathrm{Ma}$, a significant part of the transform motion has been accommodated by distributed deformation within the continent [Atwater, 1970; Sedlock and Hamilton, 1991; Powell and Weldon, 1992]. Much of this post-early Miocene deformation has been partitioned to the San Andreas fault and other faults farther west. A small but significant part of the Pacific-North American plate motion was accommodated by a distributed fault system east of the San Andreas fault in the Mojave-Sonoran desert and the southwestern Basin and Range province, referred to as the eastern California shear zone (Figure 1) [Atwater and Molnar, 1973; Atwater, 1988; Dokka and Travis, 1990a, b].

Two major reconstructions of fault systems in southern California have recently been published. Carter et al. [1987] and Dokka and Travis [1990a] proposed a reconstruction of the Mojave Desert region consistent with available paleomagnetic and geologic data. This model predicts that strike-slip faults and rotation within the central Mojave Desert and eastern Transverse Ranges have accommodated cumulative right slip of approximately $65 \mathrm{~km}$ since $\sim 10 \mathrm{Ma}$. This deformation must be accommodated by some combination of extension and strike-slip faulting in southeastern California and adjacent Arizona. Smith [1977], Powell [1981a], Joseph et al. [1982], and Matti and Morton [in press] reconstructed the southern San Andreas fault system without rotating the eastern Transverse Ranges. These reconstructions require that the San Francisquito-Fenner-Clemens Well [Crowell, 1975; Smith, 1977] fault, a hypothesized early trace of the San Andreas system, accumulated 90 to $170 \mathrm{~km}$ of right slip between 20 and $12 \mathrm{Ma}$ to match right slip on the southern part of the San Andreas fault system with the consensus value of $315 \pm 10 \mathrm{~km}$ determined in central California [Powell and Weldon, 1992].

This paper presents a palinspastic restoration of southeastern California in the late middle Miocene consistent with the available geologic, paleomagnetic and geophysical data. The reconstruction was produced by first identifying faults for which there is evidence of late Miocene to early Pliocene activity (Figure 2). Geologic features were then matched as closely as possible across individual faults while minimizing the amount of misfit. Faults that truncate dated or presumed upper Miocene or younger strata, or that have pronounced geomorphic expression have been used for this reconstruction. Steep gravity gradients bounding gravity minima in basins between the ranges have also been treated as faults. The regional geology and geophysical data set are outlined before detailing the reconstruction. Specific predictions and geologic implications are described in the final section.

\section{REGIONAL GEOLOGY}

\section{Rocks}

Southeastern California (NE of the San Andreas fault) can be divided into geologic domains characterized differing assemblages of pre-Tertiary rocks (Figure 4; mountain ranges referred to in text are located in Figure 3). In the eastern Transverse Ranges Jurassic and Cretaceous granitoids intrude thrust faults juxtaposing two assemblages of Proterozoic metamorphic rocks [Powell, 1981a,b, 1982]. To the east, these Proterozoic crystalline rocks are intruded by progressively greater volumes of Triassic and Jurassic plutonic rocks, until the pre-Tertiary basement consists almost entirely of Triassic and Jurassic plutonic and metaplutonic rocks (Figure 4) [Dillon, 1975; Tosdal et al., 1989; Barth et al., 1990]. Jurassic supracrustal rocks are associated with the plutonic 
rocks in several places [Haxel et al., 1985; Howard and Allen, 1988], indicating that widely varying levels of the Jurassic crust are presently exposed.

The northeastern part of the region is underlain by the McCoy Mountains Formation and Maria fold and thrust belt, together referred to here as the Maria belt. The McCoy Mountains Formation is a thick section of Jurassic(?) and Cretaceous nonmarine clastic rocks [Harding and Coney, 1985; Stone et al., 1987; Tosdal, 1988] that crops out in an arcuate belt trending ENE in west-central Arizona and WNW in California [Reynolds, 1988; Jennings, 1977]. The south-dipping McCoy Mountains Formation overlies Jurassic volcanic rocks [Tosdal et al., 1989], which in turn overlie Triassic(?) and Paleozoic sedimentary rocks in the northern Palen Mountains [Stone and Kelly, 1989]. Proterozoic and Mesozoic crystalline rocks in the Maria fold and thrust belt have been emplaced south or southwestward over strongly folded and sheared Paleozoic and Mesozoic metasediments that form a complex synclinorium with a moderately north-dipping hinge surface. A structural culmination separates the lower limb of this synclinorium from the base of the southward-dipping Jurassic volcanic rocks and McCoy Mountains Formation to the south (Figure 4). Jurassic plutons intrude and are variably deformed in the Maria fold and thrust belt, but are absent in the McCoy Mountains Formation.

The boundary between the Maria belt and Jurassic-Triassic plutonic or Proterozoic metamorphic assemblages exposed to the west and south is intruded by Cretaceous plutons to the west, and marked by the south-dipping Mule Mountains thrust [Tosdal, 1988, 1990] to the south. Available data indicate the Mule Mountains thrust is latest Cretaceous in age, and that it is probably superimposed on an older Mesozoic fault zone [Tosdal, 1990]. The Late Cretaceous Cadiz Valley batholith [John, 1981; Calzia et al., 1986] (Figure 4 and 5) intrudes the western boundary of the Maria belt in the Little Maria and Coxcomb Mountains. Late Cretaceous plutons abundantly intrude Proterozoic rocks of the eastern Transverse Ranges [Powell, 1981a, 1982], but are rare within the study area east of the Cadiz Valley batholith and SE of the Little Chuckwalla Mountains (Figure 4).

The Orocopia Schist [Miller, 1944], an assemblage of meta-graywacke, greenstone, and metachert of probable Jurassic oceanic origin [Haxel and Tosdal, 1986; Haxel et al., 1987], crops out in tectonic windows through the Orocopia-Chocolate Mountains thrust system in the Orocopia Mountains and along the Chocolate Mountains anticlinorium (described below) [Crowell, 1975; Dillon, 1975; Haxel et al., 1985]. Proterozoic and Triassic-Jurassic crystalline rocks of the eastern Transverse Ranges tectonically overlie the Orocopia schist along a composite fault system of several ages, including possible Cretaceous burial structures (Chocolate Mountains thrust sensu stricto) and early to middle Tertiary unroofing structures [Frost and Martin, 1983; Haxel et al., 1985; Haxel et al., 1988; Richard, 1989; Jacobson, 1990; Richard and Haxel, 1991].

Oligocene and early Miocene volcanic rocks blanketed pre-Tertiary rocks over a broad area along the lower Colorado River [Dillon, 1975; Crowe et al., 1979; Murray, 1981; Mayo, 1990; Sherrod and Tosdal, 1991; papers in Chapter 3 of Sherrod and Nielson, in press]. They occupy the SW end of a belt of mid-Tertiary volcanic outcrop that is continuous into central Arizona [Richard and Sherrod, in press]. The volcanic rocks thin dramatically northward across a generally west-trending boundary, which parallels the Chocolate Mountains anticlinorium and the Maria belt, between the northern Kofa Mountains in Arizona and the Mule Mountains in California [Sherrod and Tosdal, 1991]. Marker units found high in the thick southern sections overlap onto pre-Tertiary rocks north of the boundary. Northward disappearance of Tertiary rocks across the Little Chuckwalla Mountains and in the eastern Orocopia Mountains suggests that this boundary continued to the west. East of the Little Chuckwalla and eastern Chocolate Mountains the early Miocene volcanic rocks were tilted to the NE or SW during a major early Miocene extension event that affected the entire MojaveSonoran desert region [Sherrod and Tosdal, 1991; Spencer and Reynolds, 1989]. In the Chocolate Mountains and Orocopia Mountains, the volcanic rocks are complexly deformed by NW-trending folds, and faults in a variety of orientations [Dillon, 1975; Crowell, 1975].

Tertiary(?) sedimentary breccia and megabreccia crop out in the Palen Pass area, northern McCoy Mountains, central McCoy Mountains [Stone and Pelka, 1989], and between the Little and Big Maria Mountains [Ballard, 1990]. A north-trending fault in the central McCoy Mountains cuts similar sedimentary breccia. Basalt dated at $6.2 \mathrm{Ma}$ [Stone and Kelly, 1989] overlies sedimentary breccia in the northern Palen Mountains. These breccias postdate the uplift and exposure of the McCoy Mountains Formation and the Late Cretaceous Cadiz Valley batholith. They are spatially associated 
with NW-trending faults that have right separation, which may be early Miocene normal faults or late Miocene strike-slip faults.

\section{The San Andreas fault}

The central San Andreas fault became active between 20 and $17 \mathrm{Ma}$ [ODay and Sims, 1986; Graham et al., 1989; Powell and Weldon, 1992]. Powell and Weldon [1992] interpret that the San Francisquito-Fenner-Clemens Well [Crowell, 1975; Smith, 1977] fault (see Figure 12 for reconstructed configuration) was the southern continuation of the San Andreas fault at this time, and projected southeastward from the southem Orocopia Mountains with between 90 and $170 \mathrm{~km}$ of right slip. Middle Miocene strata overlap the Fenner and San Francisquito segments of the San Francisquito-Fenner-Clemens Well fault, which thus became inactive 12-13 Ma [evidence summarized in Powell and Weldon, 1992, p. 446. The active trace of the southern San Andreas fault system became the San Gabriel fault at this time [Crowell, 1982; Powell and Weldon, 1992]. This fault was linked to the NW with the central San Andreas fault. To the SE, the San Gabriel fault was probably linked with normal faults in the Gulf of California region, which was undergoing extension starting between 12 and $10 \mathrm{Ma}$ [Stock and Hodges, 1989]. Such a geometry would not require the San Gabriel fault to have continued much to the SE beyond its present intersection with the San Andreas fault. By $5 \mathrm{Ma}$, Baja California was fully transferred to the Pacific plate [Stock and Hodges, 1989], and movement on the San Gabriel fault had essentially ceased [Crowell, 1982].

The SW boundary of the reconstruction presented here is the San Andreas fault system along the northeastern margin of the Salton Trough. Slip on the active San Andreas fault is transferred southward across the Salton Trough from the vicinity of the northeastem Chocolate Mountains [Crowell, 1981; Irwin, 1990]. Southeast of this transition the Sand Hills seismicity lineament [Larsen and Reilinger, 1991] and Algodones fault [Olmstead et al., 1973] form the southeastern boundary. Except at the northwestern end of its trace within the study area, the surface trace of this boundary is entirely in Pliocene and younger sediments. The Sand Hills seismicity lineament and Algodones fault are inferred to represent progressively abandoned traces of the San Andreas fault [Larsen and Reilinger, 1991], but also probably have significant components of normal slip related to the formation of the Salton Trough [e.g. Babcock, 1974; Olmstead et al., 1973]. The San Andreas system along the southwestern boundary of the study area has accumulated about $160 \mathrm{~km}$ of right slip since 5-6 Ma [Dillon, 1975; Matti and Morton, in press]. Thus, the southwestern boundary of the reconstruction is not the fault system that was active during the late Miocene. The orignial, late MiocenePliocene boundary is now buried under younger sediments in the Salton Trough and obscured by subsequent deformation in the San Gabriel Mountains. Because a detailed reconstruction of relationships across the San Andreas fault is beyond the scope of this paper, I have used a boundary approximately along the SW margins of the present mountain ranges in the reconstruction.

\section{Otherstructures}

The Chocolate Mountains anticlinorium is a discontinuous series of structural culminations that extends from the eastern Chocolate Mountains in California to the Castle Dome Mountains in Arizona [Haxel and Dillon, 1978; Haxel et al., 1985]. Outcrops of Orocopia Schist in the vicinity of the Colorado River are associated with the basal part of the Tertiary section, but these are always in fault contact with the schist. The distribution, but generally not the strike and dip, of these Tertiary rocks indicates that the structural culmination was active after the inception of volcanism. The pattern of structures in Tertiary volcanic rocks undergoes a dramatic change as the anticlinorium is approached from the north in ranges in Arizona [Richard, 1989]. North of the anticlinorium, strata strike $\mathrm{N}$ to NW, and dip NE in a series of relatively simple tilted blocks typical of those in regions affected by early Miocene extension throughout the Basin and Range. Near the Chocolate Mountains anticlinorium, strikes are generally more easterly, and the fault arrays become complex and difficult to generalize, but progressively older Tertiary volcanic rocks are predominant on the crest of the Chocolate Mountains anticlinorium. Along this crest the basal volcanic units are involved in W-to NW-trending folds. Innumerable faults disrupt the contact between Tertiary and pre-Tertiary rocks, but because short segments of intact depositional contact are commonly present (always with pre-Tertiary 
rocks in the hanging wall of the Chocolate Mountains 'thrust'), these contact are essentially depositional contacts across which minor slip has accumulated [Sherrod and Tosdal, 1991]. Along the Colorado River south of the anticlinorium, Tertiary strata strike NW and dip SW, again in a pattern typical of early Miocene extended terranes.

The composite late Mesozoic(?) and Tertiary normal fault system that exhumed the Orocopia schist [Haxel et al., 1985; Jacobson, 1990; Richard and Haxel, 1991] is intruded by early Miocene hypabyssal intrusive rocks in the Chocolate Mountains [Dillon, 1975; S. M. Richard and D. R. Sherrod unpublished observations], Middle Mountains [Richard, 1989], and Castle Dome Mountains [Grubensky and Haxel, in press]. These faults are also overlapped by the conglomerate of Bear Canyon [Dillon, 1975; Crowe, 1978; ], overlain in turn by basalt lavas of Black Mountain which have yielded K-Ar dates of $13.4 \pm 2.6 \mathrm{Ma}$ [Crowe, 1978] and 9.6 $\pm 1.8 \mathrm{Ma}$ [Eberly and Stanley, 1978]. Structures and facies patterns in early to middle Miocene volcanic rocks in the Trigo Mountains are also continuous [Sherrod and Tosdal, 1991] and unbroken by continuous NW-trending structures (Figure 8,10). A complex array of younger faults cuts conglomerate units similar to the Bear Canyon conglomerate [Sherrod and Tosdal, 1991; Richard, unpublished mapping].

Presently, no faults east of the Sheep Hole fault in southeastern California are known to be active [Fugro Inc., 1975, p. 122-125]. The east-trending Blue Cut , Smoke Tree Wash, Porcupine Wash, and Pinto Mountain faults (Figure 2) cut Pleistocene(?) sediments in the eastern Transverse Ranges [Hope, 1966; Powell, 1981a]. Seismicity in southeastern California is concentrated in the western part of the eastern Transverse Ranges, particularly under the Little San Bernardino Mountains [Fuis et al., 1977; Williams et al., 1990]. Many of the fault plane solutions indicate events on steeply dipping, NE- to east-trending left-lateral faults, with near-horizontal T-axes trending WNW [Williams et al., 1990].

\section{GRAVITY AND PALEOMAGNETIC DATA}

Short-wavelength negative isostatic gravity anomalies are generally associated with thick accumulations of low-density sediments [Jachens and Griscom, 1985]. Gravity maps can thus be used to delineate young basins filled with relatively uncompacted sediments. Steep gravity gradients along the margins of such basins are interpreted to indicate fault boundaries. The isostatic residual gravity map of the lower Colorado River region [Mariano et al., 1986], and the Bouguer gravity map of the southeastern Mojave Desert [Rotstein et al., 1970] were used to identify young sedimentary basins and probable faults bounding them. The locations of negative gravity anomalies greater than $25 \mathrm{mgal}$ are shown in Figure 2 to indicate the probable locations of thick accumulations of uncompacted sediment.

Paleomagnetic data indicate clockwise declination anomalies from seven sites in the eastern Transverse Ranges; three other sites produced uninterpretable results. Four of these sites yield consistent results indicating an average of $41 \pm 8^{\circ}$ of clockwise rotation (Figure 2). Volcanic rocks that have yielded $\mathrm{K}$-Ar apparent ages as young as $10.2 \pm 2.0 \mathrm{Ma}$ are fully rotated [Carter et al., 1987]. Sites from the early Miocene Diligencia Formation of the Orocopia Mountains [Crowell, 1975; Crowell, in press] yielded results indicating 107 to $164^{\circ}$ of clockwise rotation; these more extreme apparent rotations are attributed to deformation associated with the adjacent Clemens Well fault [Carter et al., 1987]. A clockwise declination anomaly from basalt flows dated at $6.2 \pm 0.2 \mathrm{Ma}$ in the northern Palen Mountains [Stone and Kelly, 1989] is probably not representative of the entire Palen Mountains. The analyzed flows in the Palen Pass area lie in a zone of complex deformation adjacent to the Packard Well fault (Figure 5). The pattern of structure contours drawn on the base of the basalt suggest that the flows are cut by minor north trending faults. Thus, the clockwise rotation indicated by the paleomagnetic data from the northern Palen Mountains is here interpreted as the result of local deformation related to movement on the Packard Well fault. Basalt flows in the northeasternmost Eagle Mountains [Carter et al., 1987] and correlative flows between the Eagle and Coxcomb Mountains [B. Adams, written communication, 1991] show no declination anomalies. These flows have yielded K-Ar whole-rock apparent ages of $7.8 \pm 0.7$ [Carter et al., 1987] and $4.5 \pm 0.3$ [Calzia et al., 1986]; the younger age is considered more reliable.

Paleomagnetic data from volcanic rocks in the domain of NW-trending faults in the Mojave Desert north of the Pinto Mountain fault are interpreted to indicate early Miocene (pre 18.5 Ma) 
clockwise rotations of about $50^{\circ}$ [Ross et al., 1989]. Outcrops of Peach Springs tuff [Young and Brennan, 1974; Nielson et al., 1990] within this domain record small $\left(<13^{\circ}\right)$ clockwise and counterclockwise rotations from three sites. Declination anomalies $>10^{\circ}$ from two of these sites are attributed to local deformation related to adjacent faults [Wells and Hillhouse, 1989]. These data preclude post-early Miocene rotation of NW-trending fault blocks north of the Pinto Mountain fault.

A series of paleomagnetic studies of volcanic rocks in southwestern Arizona and southeastern California by students at San Diego State University [Butterworth, 1984; Callian, 1984; Costello, 1985; Veseth, 1985] yielded inconclusive results that suggest the possibility of rotations in the region near and south of the Chocolate Mountains anticlinorium (Figure 6). A total of 34 localities were drilled in upper Oligocene and Miocene volcanic rocks, generally with poor stratigraphic framework to correlate units between sections. Typically 3-5 individual flow units were sampled at each locality, too few to average secular variation. When site-mean directions for all localities are plotted on a map, those north of the eastern Chocolate Mountains scatter about the expected Miocene direction, whereas those to the south are consistently deflected clockwise from the expected direction. The volcanic rocks in the region sampled, including many of the sampled flows, typically dip NE and SW due to early Miocene crustal extension [Sherrod and Tosdal, 1991]. Thus, if there was vertical axis rotation, it occurred before the final tilting of the volcanic rock. In summary, this inconclusive data set suggests clockwise rotation in the region near the Chocolate Mountains anticlinorium, but if real, the rotation occurred between early Miocene and middle Miocene. More work is necessary to
clarify this data set.

\section{RECONSTRUCTION}

Figure 7a shows the proposed reconstruction of southeastern California and adjacent Arizona at about $10 \mathrm{Ma}$. Polygons have been drawn to enclose blocks accounting for all area in the reconstructed map. These blocks have been displaced and rotated using the fault array and slips specified in Figure 2 and Table 1 to produce the configuration at about $4 \mathrm{Ma}$ (Figure $7 \mathrm{~b}$ ), before Quaternary deformation in the Pinto Mountains region. The locations of gaps indicates regions that have undergone extension, and overlaps indicate regions that have been contracted.

The fault array and rotations indicated by geologic and geophysical evidence described has been palinspastically restored based on matching geologic features around a circuit from the Chocolate Mountains, north through the Trigo and Dome Rock Mountains, NW along the Maria Fold and thrust belt, west through the Cadiz Valley batholith to the Pinto Mountains, then south through the eastern Transverse Ranges. Because of the paucity of data in the Little Chuckwalla and western Chocolate Mountains area, and the geological discontinuities across the Chuckwalla Valley, the circuit does not close. Elucidation of geologic relations in this gap will serve as an important test of the reconstruction. I have assumed that the average strike of the NW-trending faults in the southeastern Mojave Desert ( $145^{\circ} \mathrm{E}$ ) represents the direction of shear across the entire deformation zone. Thus, faults striking more westerly are expected to have a contractional component of displacement and faults with more northerly strike an extensional component of displacement.

\section{Chocolate Mountains region}

The eastern Chocolate Mountains have been reconstructed by unslipping the east-trending Mammoth Wash and Black Eagle faults as suggested by Dillon [1975, p. 206] (Figure 8, Table 1).
The Black Eagle fault curves to the NE to parallel NE-trending faults in the eastern end of the Chocolate Mountains [Dillon, 1975]. I hypothesize that the Mammoth Wash fault has a similar arcuate trace beneath alluvium on the north side of the range. These NE-trending faults are interpreted to connect with a NE-trending fault system bounding the westem side of the Cibola Basin SE of the Palo Verde Mountains. As discussed below (eastern Transverse Ranges), the southeastern boundary of the rotating eastern Transverse Ranges is located in the central Chocolate Mountains. The westward fanning of fault orientation from NE to $\mathbf{E}$ in the eastern Chocolate Mountains (Figure 8) suggests that the east-trending faults may have originated in a more northeasterly orientation and have rotated to their present east trend as a result of late Miocene deformation. A sliver of Bear Canyon conglomerate deformed within the Mammoth Wash fault zone attests to its young age. Extension in 
the Milpitas Wash basin accommodated left slip on these faults. As a result of slip on the arcuate Mammoth Wash and Black Eagle faults, as well as distributed deformation, I propose that rocks north of the Mammoth Wash fault have been rotated clockwise about $25^{\circ}$, while rocks at the eastern end of the Chocolate Mountains have not been rotated. Gaps and overlaps in this area in Figure $7 \mathrm{~b}$ are mostly due to reconstruction of distributed deformation using two discrete faults. The Mammoth Wash and associated faults thus accommodated differential rotation, and escape of the eastern Chocolate Mountains to the SE as the Milpitas Wash basin was formed.

The Picacho-Peter Kane area is located between a NE-trending zone of left-slip and and northNW trending zone of right slip (Figure 8,9). The pattern of structural culminations and troughs along the anticlinorium is offset left-laterally about $3.5 \mathrm{~km}$ along the NE-trending Vinagre Wash fault zone (Figure 9). Extensional transfer zones linking slip between the eastern Chocolate Mountains and Peter Kane Mountain with the northeastern continuation of the Mammoth Wash fault have formed small basins east and west of Midway Mountain. A similar zone of right slip, here named the Laguna fault system, projects SSE from the southern Cibola Basin. A system of linked NW trending right-normal oblique slip faults and north-trending normal faults has formed as series of small basins in the southern Trigo Mountains and Picacho area (Figure 8). Northerly trending faults juxtapose Bouse Formation against older rocks of the Trigo Mountains at the northern end of this zone [Sherrod and Tosdal, 1991]. Horizontal striations are abundant on NW-trending vertical minor faults cutting the Bear Canyon conglomerate at its type locality in the southern part of the zone. Maximum slip across the Laguna fault system has been estimated by assuming that the typical $20^{\circ}$ maximum dip of Bear Canyon-like conglomerates in basins within the zone is representative of tilting of all rocks along a NNE transect across the zone, and that normal faults bounding the basins were originally vertical. With these assumptions, the extension is $6.5 \%$ across a zone $30 \mathrm{~km}$ wide [see formulas in Wernicke and Burchfiel, 1982], or about $2 \mathrm{~km}$, which must be equal to the strike-slip on faults linking the basins. Distributed deformation across the wedge between the Vinagre Wash and Laguna fault systems is probably responsible for the complex pattern of rock distribution and faulting on all scales in the Picacho-Peter Kane area, but associated deformation has not significantly offset the trace of the Chocolate Mountains anticlinorium.

\section{Linked strike-slip and extensional fault system on eastern boundary}

As summarized by Howard and Miller [1992], a number of NW-trending basins and ranges in the southeastern Mojave Desert may be cut or bounded by right-lateral faults, but observed separations are imprecise and can generally be explained by either early Miocene normal faulting or late Miocene-Pliocene right slip. As discussed below (under Timing), faults cutting Pleistocene sediments may record minor Quaternary reactivation. Direct evidence for post-early Miocene, preQuaternary right-slip is best documented along the Cibola fault in the Trigo Peaks area of western Arizona [Richard et al., 1992], and along the Packard Well fault (Figures 2 and 5). These NWtrending faults and the basins between them form a linked array of strike slip and normal faults similar to the Laguna fault zone, but on a larger scale.

The Cibola fault zone encompasses a series of NW-trending faults the cut through the low divide between the Trigo Peaks and Trigo Mountains, southwestern Arizona [Richard et al., 1992]. Consistent separation of west-dipping normal faults in the Gould Wash area and east-dipping stratigraphic contacts in the northern Middle Mountains indicate approximately $7 \mathrm{~km}$ of right slip across the Cibola fault zone. The fault is overlapped by the topographically highest and youngest basinfilling alluvium, lithologically equivalent to the old alluvium (QTs) which overlaps the Packard Well fault [Stone and Kelley, 1989]. These sediments are probably similar in age to the youngest part of the Bouse Formation, deposited between $\sim 8$ and $\sim 4$ Ma [Metzger et al., 1973; Buising,1990, 1992; Sherrod and Tosdal, 1991], and overlying Colorado River alluvium, which predated the first major period of downcutting along the lower Colorado River [Metzger et al., 1973]. There is no evidence of significant deformation in the Bouse Formation along the trace of the Cibola-Packard Well fault, but the data are insufficient to rule out trace slip deformation during deposition of the unit. To the SE, strike slip on the Cibola fault is transferred to extension on normal faults that bound the Middle and Castle Dome Mountains [Richard et al., 1992]. 
In the Packard Well area between the Granite and Palen Mountains, two moderately to steeply north-dipping, east-trending fault splays bound a synclinally folded sliver of undated Tertiary fanglomerate [Stone and Kelly, 1989]. I interpret that minor faulting and apparent rotation of basalt lava about $4 \mathrm{~km}$ south of the Packard Well fault is related to deformation on the Packard Well fault, which was thus active after 6.2 \pm 0.2 [Stone and Pelka, 1989]. Old alluvium (QTs of Stone and Pelka, 1989), typically interpreted to be early Pleistocene or late Pliocene in age in this region [Howard and Miller, 1992], overlies the fault trace and is not deformed. The Palen Mountains must be translated about $4.5 \mathrm{~km}$ to the SE in order for the southeastern contact of the Cadiz Valley batholith to project from the westem Little Maria Mountains to the southem Coxcomb Mountains without being exposed south of the Packard Well fault (Figure 5). However, because the Packard Well fault trends more easterly than the NW-trending faults to the north, which are interpreted to parallel the regional shear direction, it is likely to have a component of contraction. The northerly dip and reverse separation on the northem fault, and folding of the fanglomerate between the northern and southern splays of the Packard Well fault are consistent with contraction, which reduces the strike slip necessary to fit the southeastern contact of the Cadiz Valley batholith between the Palen and Granite Mountains, particularly if the contact dips to the south. A total slip of $2.5 \mathrm{~km}$ in a NW direction parallel to the inferred shear direction $\left(145^{\circ}\right.$ ), partitioned into $2.3 \mathrm{~km}$ of right slip and $.9 \mathrm{~km}$ of contraction has been reconstructed across the Packard Well fault.

Relatively minor NW-trending high-angle faults exist NE of the Cibola-Packard Well fault. Right separation across these faults could be due to either right slip or normal slip (see Table 1 and Figure 2), and the time of movement is poorly bracketed [Howard and Miller, 1992], so that interpretation of the slip distribution on these faults is somewhat arbitrary. Breccia deposits, similar to those underlying the $6.2 \mathrm{Ma}$ basalts in the northern Palen Mountains, are cut by NW-trending high angle faults in the Iron Mountains [Miller and Howard, 1985] and McCoy Mountains [Stone and Pelka,1989] and are present between the Big and Little Maria Mountains [Stone, 1990]. Negative gravity anomalies suggest the presence of young basins under the Palo Verde Valley and between the McCoy, Palen and Coxcomb Mountains. In the reconstruction, $9 \mathrm{~km}$ total right slip on the Cibola and Laguna fault systems, along with $4 \mathrm{~km}$ of extension that is geometrically allowable through the southeastern boundary of the rotating eastern Transverse Ranges, has been transferred by extension in the the Palo Verde Valley and between the McCoy, Palen and Coxcomb Mountains to right slip faults in the southeastern Mojave Desert. This style of deformation is similar to that proposed along the Laguna fault system, but on a larger scale. The distribution of Oligocene-early Miocene tuffs and the boundary of thick volcanic sections in western Arizona (Figure 10) rules out the existance of other large strike slip faults in westem Arizona. The total $13 \mathrm{~km}$ right slip NE of the Sheep Hole fault is the maximum amount of right slip that can be accommodated in this region without necessitating the existence of unrecognized faults in western Arizona or producing major overlaps in reconstructing the region between the Salton Creek-Aztec Mine fault and the Colorado River.

\section{Pinto Mountain fault}

The Pinto Mountain fault [Hill, 1928] bounds the northern edge of the eastern Transverse Ranges. Pleistocene fanglomerates along the western part of the fault are displaced about $9 \mathrm{~km}$ in a left-lateral sense from their sources [Dibblee, 1967; Grimes, 1987; Bacheller, 1978; Howard, pers. comm., 1992], while basement rocks are separated $19 \pm 3 \mathrm{~km}$ in a left-lateral sense in the Twentynine Palms area [Dibblee, 1982; Bacheller, 1978] (Figure 11a, Table 1). Just east of Twentynine Palms, the Pinto Mountain fault intersects the Mesquite fault and several other NW-trending, right-lateral faults that form prominent lineaments in the basin area north of the Pinto Mountains. These faults both offset and are offset by the Pinto Mountain fault, suggesting that at least some of their displacement has been coeval [Bacheller, 1978; Dibblee, 1982, 1992a]. South of the intersection, uplift of Twentynine Palms Mountain by eastward thrusting on the southern continuation of the Mesquite fault absorbs some of the slip on the Pinto Mountain fault [K. A. Howard, pers. comm., 1991]. The Pinto Mountain fault bifurcates into several strands in the vicinity of this intersection, all of which show right separations across the NW-trending faults. East of the Valley Mountain fault at the eastern edge of the intersection zone there is no surface expression of the Pinto Mountain fault north of the range front, except for one ridge of possible old alluvium [Howard and Allen, 1988] north of the eastern Pinto Mountains. Southward offset of the Pinto Mountains range front across the inter- 
section with the Mesquite Lake-Valley Mountain fault system indicates that development of the range front predates the most recent displacement on these faults. The continuity of the Sheep Hole and Coxcomb Mountains across the eastern projection of the Pinto Mountain fault requires that the displacement is $0 \mathrm{~km}$ at the eastern end of the fault [Hope, 1966; Powell, 1981a].

Before proceeding with the middle Miocene reconstruction, Quaternary displacement on the Pinto Mountain fault must be reconstructed. Scarps in alluvium and recent seismic activity indicates that the Mesquite Lake fault and faults to the west are presently active [Dibblee, 1967, 1968; Beeby and Hill, 1975; McJunken, 1980]. Because there is no evidence for recent activity east of the intersection with the Mesquite Lake-Valley Mountain fault zone, and the fault cannot extend east of the eastern end of the Pinto Mountains [Hope, 1966, $9 \mathrm{~km}$ of slip on the Pinto Mountain fault requires some combination of extension north of the fault and contraction south of the fault. Recent documentation of reverse faulting along the southeastern continuation of the Mesquite Lake fault into the Pinto Mountains [K. A. Howard, pers. comm, 1991] suggest that left slip is transferred to thrusting at the intersection with the NW-trending Mesquite Lake-Valley Mountain fault system, in a manner analogous to the intersection of the Garlock and Death Valley fault zones [Bacheller, 1978; Spencer, 1990]. The Mesquite Lake-Valley Mountain fault system offsets the Pinto Mountain fault by 3-3.5 $\mathrm{km}$ to the right [Bacheller, 1978]. The Pinto Mountain and Mesquite Lake-Valley Mountain faults have thus been reconstructed by unslipping the Mesquite Lake-Valley Mountain faults to straighten the trace of the Pinto Mountain fault, and by unslipping $9 \mathrm{~km}$ of contraction on two thrust faults--the mapped southern Mesquite Lake reverse fault and a second, older, reverse fault hypothesized at the intersection of the Valley Mountain fault with the Pinto Mountain fault.

This reconstruction predicts $10 \pm 3 \mathrm{~km}$ of pre-Quaternary left slip on the central Pinto Mountain fault, which must decrease to $0 \mathrm{~km}$ at its eastern end. The Pinto Mountain fault truncates NWtrending right slip faults in the Mojave Desert north of the eastern Transverse Ranges. As discussed below, this east-trending fault formed the boundary between the rotating eastern Transverse Ranges and non-rotating Mojave Desert region during late Miocene time. The geometry in Figure 11c shows that along such a boundary, left slip will increase from 0 at the eastern termination westward to some maximum value that is a function of the amount of rotation (equations in Figure 11b). As discussed below, a $39^{\circ}$ rotation of the eastern Transverse Ranges would produce $9.8 \mathrm{~km}$ of left slip across the Pinto Mountain fault at Copper Mountain, a value close to the geologically estimated slip.

\section{Eastern Transverse Ranges}

Two lines of evidence, one paleomagnetic, the other geologic, indicate that the eastern Transverse Ranges have been rotated approximately $40^{\circ}$ clockwise since the late Miocene. Paleomagnetic data summarized above indicate $41^{\circ}$ of clockwise rotation of the Pinto and Eagle Mountains blocks between $\sim 10$ and 4.5 Ma. Data from the Orocopia Mountains are consistent with this clockwise rotation. Interpretation that the entire eastern Transverse Range domain has rotated as a series of rigid fault-bounded blocks requires that the declination anomalies determined from areally restricted volcanic rocks represent rotation of entire mountain-range-scale blocks. The continuity of the linear, east-west trending faults bounding the major blocks that make up the eastern Transverse Ranges and the continuity of structures mapped by Powell [1981a, 1982] within these blocks both support this interpretation.

The second line of evidence for rotation is based on consideration of the geometry of the interaction of NW-trending faults in the southeastern Mojave Desert with the east-trending Pinto Mountain fault. Based on geologic evidence, the total right slip on the five faults which interact with the Pinto Mountain fault between Copper Mountain and the eastern termination of the Pinto Mountain fault (Calico, Pisgah-Bullion, Delta, Cleghorn Pass, Cleghorn Lakes, Figure 11a) ranges between 30.4 and $57.9 \mathrm{~km}$ (Table 2a) [Dokka and Travis, 1990a; Howard and Miller, 1992; Jagiello et al., 1992]. Paleomagnetic evidence discussed above indicates that the blocks between the NW-trending faults have not rotated. Figure $11 \mathrm{~b}$ describes the geometric and trigonometric relationships for regional deformation by systems of strike-slip faults [Garfunkel and Ron, 1985]. Given the measured fault displacements, the width of the domains over which the NW- and west-trending faults are distributed, and the present angles between the faults and domain boundaries, the trigonometric relationships allow calculation of the amount of rotation (Table $2 \mathrm{~b}$ ). As can be seen in Table $2 \mathrm{~b}$, there is 
no rotation that will produce the observed slips on the fault systems if the eastern boundary (Sheep Hole fault) remains rigid. Either the rotation is $\sim 20^{\circ}$ and slip on the NW-trending faults is $\sim 18 \mathrm{~km}$, or slip on the Pinto Mountain fault is $\sim 11 \mathrm{~km}$, and slip on west-trending faults in the eastern Transverse Ranges is $-55 \mathrm{~km}$. Both of these cases require some estimated slip or rotation values to be greatly in error.

The measured fault slip and paleomagnetically determined rotation can be reconciled if the eastern boundary of the rotating domain (the Sheep Hole fault) rotates slightly during the deformation. A line drawn between the northeastern corner of the Eagle Mountains and the easternmost part of the Chuckwalla Mountains trends $\mathrm{N} 153^{\circ} \mathrm{E}$, about $15^{\circ}$ more southerly than the Sheep Hole fault; such a change is strike is necessary in order for the Sheep Hole fault to project on the SW side of the Coxcomb Mountains. The Sheep Hole fault is interpreted to have been originally straight, and the change in strike is attributed to rigid body rotation of the entire eastem Transverse Ranges block along with its eastern boundary. A $39^{\circ}$ rotation of the eastern Transverse Ranges, accommodated by $15^{\circ}$ of rigid body rotation, and $24^{\circ}$ of rotation associated with slip on west-trending faults (Figure 11c) produces a best fit to the fault slip estimates, and lies within the error margin of the paleomagnetically determined rotation (Table $2 \mathrm{~b}$ ).

The similarity of rocks across the Sheep Hole fault between the Sheep Hole, Coxcomb and Pinto Mountains indicates that this juncture may be considered fixed relative to the rotating blocks, consistent with the termination of the Pinto Mountain fault. No right slip has been reconstructed on the Sheep Hole fault NW of its intersection with the original Pinto Mountain fault (compare Figures 7a and b). This results in $4.5 \mathrm{~km}$ of left slip between the eastern Pinto Mountains and Sheep Hole Mountains. If some of the allowed right slip NE of the Sheep Hole fault is partitioned to this fault, no slip would be necessary at its intersection with the Pinto Mountain fault, but this would require additional extension to the $\mathrm{SE}$ in a transfer zone linking this slip to the present trace of the San Andreas fault. As mentioned previously, the assignment of relatively small slip to individual faults northeast of the Sheep Hole fault is somewhat arbitrary.

The pivot point for the late rigid body rotation is located near the pass between the Eagle and Coxcomb Mountains. The rigid body rotation of the eastern Transverse Ranges results in extension to produce the basins indicated by negative gravity anomalies in the Chuckwalla Valley, Palo Verde Valley, Milpitas Wash Basin, and the unnamed basin west of the Little Mule Mountains (Figure 2). The arcuate Mammoth Wash-Black Eagle Mine and Vinagre Wash fault systems form the boundary of this rotating and extending domain, allowing differential rotation in a manner analagous to that observed across listric normal faults (c.f. Wernicke and Burchfiel, 1982). This model also predicts that the Pinto Mountain fault was active longer than other east-trending faults in the eastern Transverse Ranges if the rigid body rotation phase occurs at the end of the deformation event.

Because the bounding faults between the Salton Creek Fault-Aztec Mine Wash fault and Pinto Mountain fault are all parallel, accommodation of the rotation requires that the faults and the rocks adjacent to the faults have rotated by the same amount, and that all the faults must have been simultaneously active [Garfunkel and Ron, 1985]. At present, only faults north of the Chiriaco fault are interpreted to be active, and the faults apparently become more active (or more recently active) to the north [Fuis et al., 1977; Powell, 1981a]. This discrepancy between the timing of recent activity on these faults and the evidence for rotation can be reconciled if the faults have a two stage history of movement (see discussion of timing below).

The southeastern boundary the rotating eastern Transverse Ranges has been placed within the Chocolate Mountains and Little Chuckwalla Mountains. Mesozoic structures east of this boundary region (Chocolate Mountains thrust [Dillon et al., 1990] and Mule Mountains thrust [Tosdal, 1990]) are not rotated relative to outcrops of the same structures further east. The Salton Wash-Aztec Mine Wash fault (Figure 2) is parallel to other east-trending left-lateral faults in the eastern Transverse Ranges, indicating that this fault and the rocks adjacent to it have rotated the same amount as the rest of the eastern Transverse Ranges. The geology of the central and western Chocolate Mountains, Little Chuckwalla and Little Mule Mountains is too poorly known to allow a detailed reconstruction of late Miocene deformation in this area. I have arbitrarily split the Little Chuckwalla Mountains along a NW-trending fault in the central part of the range (shown in the southeastem comer of Powell's [1981a] map of the region), and broken the Chocolate Mountains into three pieces along major washes that split the range. These pieces have been placed in the reconstruction as dictated by 
their relationship to adjacent ranges. They are shown mostly to demonstrate that unacceptable overlap is not required in this region. Four $\mathrm{km}$ of extension across this zone has also been reconstructed to accommodate extension in the valley between the Palen and Coxcomb Mountains and right slip in the Cadiz Valley; any right-slip on the Sheep Hole fault or faults in Dry Lakes Valley would also have to be transferred SW through this boundary region. The actual geologic relationships in this region are surely much more complicated and their elucidation will serve as a test of the reconstruction proposed here.

At the NW edge of the domain, the reconstruction predicts a large overlap between the western Pinto Mountains and San Bernardino Mountains. This overlap is a result of the non-rotation of the San Bernandino Mountains and the absence of recognized late Miocene right-slip faults west of the Camp Rock fault. The overlap requires the existence of late Miocene thrust faults that lose displacement eastward. The Squaw Peak thrust system of Meisling and Weldon [1989] is a candidate for such a thrust; the early uplift of the San Bernardino Mountains may in part accommodate the rotation of the Pinto Mountains. Some clockwise rotation of the San Bernardino Mountains or the presence of late Miocene right slip faults in the eastern part of the range would reduce the amount of contraction required. Because of difficulties in reconstructing the Quaternary deformation around the western Pinto Mountains, the relationships here are only schematic, but some contraction between the Pinto and San Bernardino Mountains seems required.

I have used slip estimates for faults of the eastem Transverse Ranges from Hope [1966] and Powell [1981a]. The Salton Wash and Aztec Mine Wash faults have been treated as continuous structures (after Powell,1981a). Several faults in the eastern Transverse Ranges with several $\mathrm{km}$ of separation attributed to left-slip are not continuous across the entire domain. In order to maintain material continuity slip on these faults has been linked with other faults to cross the entire domain as indicated in Figure 2. Some of this linkage must be by distributed deformation because lithologic units can be mapped across the trace of the faults (e.g. Smoke Tree Wash and Victory Pass faults in the Hexie and Eagle Mountains [Powell, 1981a]). Some Quaternary disruption of the east-trending faults in the central eastern Transverse Ranges also appears possible.

\section{TIMING}

There $\mathrm{K}-\mathrm{Ar}$ dates as young as $10 \pm 2 \mathrm{Ma}$ have been obtained from basalt lavas in the eastern Transverse Ranges that record the full rotation observed [Carter et al., 1987]. 4.5 Ma basalt between the Eagle and Coxcomb Mountains appear to overlap the trace of the Sheep Hole fault, and paleomagnetic data indicate that these basalt lavas are not rotated [Carter et al., 1987; B. Adams, written comm., 1990]. Basalt lava in the northern Palen Mountains with a clockwise declination anomaly of $31^{\circ} \pm 11^{\circ}$ have yielded a $\mathrm{K}-\mathrm{Ar}$ apparent age of $6.4 \pm 0.2 \mathrm{Ma}$, indicating that the Packard Well fault was active after this time (see above). Dokka and Travis [1990a] report that movement on the Calico fault, interpreted to have been active during rotation of the eastern Transverse Ranges, post-dates deposition of the Barstow Formation, which ended after 13.4士.2 Ma [MacFadden et al., 1990]. Rotation of the eastern Transverse Ranges is thus interpreted to have occurred between $10 \pm 2$ and 4.5 $.2 \mathrm{Ma}$.

The timing of movement on other faults in SE California is based on establishing the age of mostly unfossiliferous, unconsolidated to moderately indurated alluvium cut by the faults. Howard and Miller [1992] interpret that faults in Cadiz and Dry Lake Valleys, and the Sheep Hole and Bullion Mountains cut alluvium they interpret to be as young as early Pleistocene. Clasts in lower Pleistocene alluvium may be separated by up to $2 \mathrm{~km}$ from sources NE of the Sheep Hole fault [Jagiello et al., 1992]. Otherwise the magnitude and sense of Pliocene or Pleistocene movement on these faults is unknown.

The Pinto Mountain fault is presently active west of its intersection with the active Mesquite Lake-Valley Mountain fault system (see discussion of Pinto Mountain fault above) [Hope, 1966; Bacheller, 1978; Powell, 1981a]. Other NW-trending faults in the Mojave Desert west of the Mesquite Lake-Valley Mountain fault system, and east-trending faults in the eastern Transverse Ranges north of the Chiriaco fault are also apparently active [Fuis et al., 1977; Powell, 1981a]. Direct evidence of significant Quaternary movement has been found only along the Pinto Mountain and Mesquite Lake faults [Dibblee, 1968; Bacheller, 1978]. 
The discrepancy between the timing of rotation in the eastern Transverse Ranges and the youthfulness on some, but not all, of the east-trending faults in the eastern Transverse Ranges can be reconciled by a two-stage deformation history, similar to that documented in the adjacent San Bernardino Mountains [Meisling and Weldon, 1989]. Between 10 and 4.5 Ma, east-trending faults in the eastern Transverse Ranges, and NW trending faults in the Mojave Desert were active as the eastern Transverse Ranges were rotate and translated slightly to the NE. This deformation accompanied movement on the San Gabriel fault to the west, extension in the proto-Gulf of California to the south, and thrusting in the southern San Bernardino Mountains (Squaw Peak thrust of Meisling and Weldon [1989]). Erosion and sedimentation during a hiatus between $\sim 4.5$ and $\sim 1.5 \mathrm{Ma}$ obliterated the surface traces of these faults. Deformation starting $\sim 1.5 \mathrm{Ma}$ accompanied renewed thrusting in the San Bernardino Mountains and a general shift to contraction in the western and central Transverse Ranges. Quaternary displacement on the Pinto Mountain fault accumulated during this episode. Minor reactivation of older strike-slip and normal faults in the eastern Transverse Ranges and Mojave Desert is responsible for the surficial deformation observed there. This two-stage deformation history is used as a working hypothesis in this paper.

\section{DISCUSSION}

Normal faults of Late Cretaceous [Haxel et al, 1985] and Tertiary age [Crowell, 1975; Haxel and Dillon, 1978; Frost et al., 1982; Goodmacher et al., 1989; Jacobson, 1990] bound the Orocopia schist on the north side of the Chocolate Mountains anticlinorium. The reconstruction suggests that a system of normal faults, possibly of diverse ages, bounds the Orocopia Schist on the north in the eastern Chocolate Mountains, continues west into the Orocopia Mountains, and thence across the San Andreas fault as the San Francisquito fault. The normal fault systems proposed west of the San Andreas fault by Tennyson [1989] and Bohannon [1975] would thus continue eastward across the northern end of the Chocolate Mountains, to link with the Gatuna breakaway zone in the Picacho area [Tosdal and Sherrod, 1985; Sherrod et al., 1987] (Figure 8). The volcanic rocks in the northern Chocolate Mountains, Orocopia, Little Mule, Palo Verde and along the southern side of the Little Chuckwalla Mountains occupy the hanging wall of this fault system. Jurassic(?) and Cretaceous supracrustal rocks that crop out below the Tertiary section in the vicinity of the Chocolate Mountains anticlinorium in the Picacho area, Middle Mountains and Castle Dome Mountains may have been preserved in a half graben bounded on the south by Late Cretaceous or early Tertiary faults in this system [Richard, 1989].

The continuity of structures along the Chocolate Mountains anticlinorium and the distribution of early Miocene ash flow tuffs in southwestern Arizona preclude the existence of large strike-slip faults of post Oligocene age east of the eastern Transverse Ranges. Based on evidence summarized here, the total right slip NE of the Sheep Hole Fault is less than $14 \mathrm{~km}$. Dokka and Travis [1990a] interpreted that faults in the Mojave Desert that project into or east of the Sheep Hole fault (their Ludlow, Broadwell Lake, Bristol Mountains and Granite Mountains faults) have $37.5 \mathrm{~km}$ of right slip. This magnitude of slip cannot be reconciled with geologic relationships in southwestern Arizona, and transfer of this slip across southeastern California to the San Andreas fault requires significant NWSE extension between the Chocolate Mountains and Pinto Mountain fault, for which there is no evidence.

As reconstructed here, the middle Miocene Clemens Well fault in the Orocopia Mountains trends east towards Arizona. The same early Miocene features that limit late Miocene strike slip in the region apply to proposed early Miocene strike slip [Smith, 1977; Powell, 1981a; Powell and Weldon, 1992, Matti and Morton, in press] on this fault as well. About $100 \mathrm{~km}$ of right slip documented on the central San Andreas fault between 20-17 and 12-13 Ma [Graham et al., 1989; Powell and Weldon, 1992 and references therein] needs to be accounted for in southern California. The difficulty in accommodating this slip using the Clemens Well fault in southeastern California and SW Arizona requires consideration of other possibilities. Field evidence for large slip on the Clemens Well fault in the Orocopia Mountains needs to be carefully reviewed. If large slip can be demonstrated, then somehow this slip must be transferred to the Salton Trough by unrecognized structures in the Chocolate Mountains. If the field relations do not require large slip, the possibility needs to be considered that an early Miocene strike slip fault lay on the west side of the San Gabriel Mountains, or that a significant component of early strike slip on the central San Andreas was a result of rotation 
of the western Transverse Ranges [Hornafius, 1985] in a manner analogous to the right slip faults north of the Pinto Mountain fault.

The model proposed here also predicts that a line drawn along the southwestern boundary of the reconstruction between the western tip of the Pinto Mountains and the southern tip of the Cargo Muchacho Mountains changes in length from 170 to $225 \mathrm{~km}$, and rotates clockwise by $14^{\circ}$. Thus, slip estimates for the San Andreas fault that match rocks across the fault from the Pinto Mountains should be $40-50 \mathrm{~km}$ different from estimates based on matching rocks from the eastern Chocolate Mountains. These changes in the geometry of the rocks NE of the San Andreas fault will have a significant impact on reconstructions across the San Andreas system. As an example, the sketch in Figure 12 indicates how the San Gabriel-Liebre Mountain block can be restored along this boundary to match rock units both north and south of the Clemens Well fault without major strike slip on this fault. This figure is presented to suggest the possibility of new cross-San Andreas reconstructions extending this model. The complexities of discussing such reconstructions in detail is beyond the scope of this paper.

Acknowledgements: Discussions with John Crowell, Roy Dokka, Gordon Haxel, Keith Howard, John Matti, Dave Sherrod, Paul Stone, and Richard Tosdal have been instrumental in shaping the ideas presented here. Ron Blom and Robert Crippen processed the Landsat Thematic Mapper images used for geological interpretations. I thank David Sherrod, Richand Tosdal, and John Crowell for reviewing an early draft of this paper. This research was funded by NASA grant \#NAGW-1246. Institute for Crustal Studies contribution \#0070-0028TC. 


\section{REFERENCES}

Atwater, T., Implications of plate tectonics for the Cenozoic tectonics of western North America, Geol. Soc. Am. Bull., 81, 3513-3536, 1970.

Atwater, T., Plate tectonic history of the northeast Pacific and western North America, in The eastern Pacific Ocean and Hawaii, edited by D. M. Hussong et al., Geology of North America, N, pp. 21-71, Geol. Soc. Am., Boulder, Colo., 1988.

Atwater, T., and P. Molnar, Relative motion of the Pacific and North American plates deduced from sea-floor spreading in the Atlantic, Indian, and South Pacific Oceans, in Proceedings of the conference on tectonic problems of the San Andreas fault system, edited by R. L. Kovach et al., Stanford Univ. Pub., Geol. Sci. 13, pp. 136-148, 1973.

Babcock, E. A., Geology of the northeast margin of the Salton Trough, Salton Sea, California, Geol. Soc. Am. Bull., 85, 321-332, 1974.

Bacheller III, John, Quaternary geology of the Mojave Desert-eastern Transverse Ranges boundary in the vicinity of Twentynine Palms, California, M. S. Thesis, 160 pp., University of California, Los Angeles, Calif., 1978.

Ballard, S. N., The structural geology of the Little Maria Mountains, Riverside County, California, Ph.D. Dissertation, 206 pp., University of Calif., Santa Barbara, Calif., 1990.

Barth, A. P., R. M. Tosdal, and J. L. Wooden, A petrologic comparison of Triassic plutonism in the San Gabriel and Mule Mountains, southern California, J. Geophys. Res., 95, 20,049-20,074, 1990.

Bassett, A. M., and D. H. Kupfer, A geologic reconnaissance in the southeastern Mojave Desert, Calif. Div. Mines Geol. Spec. Rep. 83, 43 pp., 1964.

Beeby, D. J., and R. L. Hill, Galway Lake fault, California Geology, 28, 219-221, 1975.

Bishop, C. C., Compiler, Needles Sheet, Geologic Map of California, scale 1:250000, Calif. Div. Mines Geol., Sacramento, Calif., 1964.

Bohannon, R. G., Mid-Tertiary conglomerates and their bearing on Transverse Ranges tectonics, southern California, In The San Andreas Fault in Southern California, Spec. Rep. Calif. Div. Mines Geol., edited by J. C. Crowell, 118, pp. 75-82, 1975.

Bortugno, E. J., and T. E. Spittler, Geologic map of the San Bernardino quadrangle, California, scale 1:250,000, Regional Map Series 3A, Calif. Div. Mines Geol., Sacramento, Calif., 1986.

Buising, A. V., The Bouse Formation and bracketing units, southeastern Califomia and western Arizona: implications for the evolution of the proto-Gulf of Califormia and the lower Colorado River, J. Geophys. Res., 95, 20,11120,132, 1990.

Butterworth, J. E., Paleomagnetic investigation of Mid-Tertiary volcanic rocks in the Castle Dome and Southem Kofa Mountains, Yuma County, Southwestern Arizona, M. S. thesis, 195 pp., San Diego State Univ., San Diego, Calif., 1984.

Callian, J. T., A paleomagnetic study of Miocene volcanics from the Colorado River and mainland Mexico regions, $M$. S. thesis, 109 pp., San Diego State Univ., San Diego, Calif., 1984.

Calzia, J. P., E. DeWitt, and J. K. Nakata, U-Th-Pb age and initial strontium isotopic ratios of the Coxcomb Granodiorite and a K-Ar date of olivine basalt from e Coxcomb Mountains, southeastern California, Isochron/West, 47, 3-8, 1986.

Carr, W. J., A contribution to the structural history of the Vidal-Parker region, California and Arizona, U. S. Geol. Surv. Prof. Pap. 1430, Reston, Virginia, 1991.

Carter, J. N., B. P. Luyendyk, and R. R. Terres, Neogene clockwise rotation of the eastern Transverse Ranges, California, suggested by paleomagnetic data, Geol. Soc. Am. Bull, 98, 199-206, 1987.

Costello, S. C., A Paleomagnetic investigation of Mid-Tertiary volcanic rocks in the lower Colorado River area, Arizona and California, M.S. thesis, 109 pp., San Diego State Univ., San Diego, Calif., 1985.

Crowe, B. M., Cenozoic volcanic geology and probable age of inception of basin-range faulting in southeastern most Chocolate Mountains, California, Geol. Soc. Am. Bull., 89, 251-264, 1978.

Crowell, J. C., Geologic sketch of the Orocopia Mountains, southeastem California, in San Andreas fault, a guide to the San Andreas fault from Mexico to the Carrizo plain, edited by J. C. Crowell, Calif. Div. Mines Geol. Special Report 118, pp. 99-110, 1975.

Crowell, J. C., An outline of the tectonic history of southeastern California, in Geotectonic Development of California (Rubey Vol. 1), edited by W. G. Ernst, pp. 583-600, Prentice-Hall Inc., Englewood Cliffs, New Jersey, 1981.

Crowell, J. C., The tectonics of Ridge Basin, southern California, in Geologic history of Ridge Basin, southern California, edited by J. C. Crowell et al., pp. 25-42, Soc. Econ. Paleon. Min., Pac. Sec., Los Angeles, Calif., 1982. 
Crowell, J. C., The Diligencia Formation, Orocopia Mountains, southeastern California, in Tertiary stratigraphy of the highly extended terranes, California, Arizona and Nevada, edited by D. R. Sherrod et al., U. S. Geol. Surv. Bull., Reston, Virginia, in press.

Dibblee Jr., T. W., Geologic map of the Joshua Tree quadrangle, San Bernardino County, California, scale 1:62500, US Geol. Surv. Misc. Inv. Map 1-516, Reston, Virginia, 1967.

Dibblee Jr., T. W., Geologic map of the Twentynine Palms quadrangle, San Bemardino County, Califormia, scale 1:62500, US Geol. Surv. Misc. Inv. Map 1-561, Reston, Virginia, 1968.

Dibblee Jr., T. W., Regional Geology of the Transverse Ranges Province of Southern Califomia, in Geology and Mineral Wealth of the California Transverse Ranges, edited by D. Fife et al., p. 7-26, South Coast Geological Society, Inc., Santa Ana, CA, 1982.

Dibblee Jr., T. W., Geology and Inferred Tectonics of the Pinto Mountain Fault, eastem Transverse Ranges, California, in Deformation associated with the Neogene Eastern California Shear zone, southeastern California and southwestem A rizona, edited by S. M. Richard, Special Publication 92-1, pp. 28-32, San Bernardino County Museums, San Bernardino, Calif., 1992a.

Dibblee Jr., T. W., Geology and Inferred Tectonics of the Pinto Mountain Fault, eastern Transverse Ranges, California, in Deformation associated with the Neogene Eastern California Shear zone, southeastern California and southwestern Arizona, edited by S. M. Richard, Special Publication 92-1, pp. 28-32, San Bernardino County Museums, San Bernardino, Calif., 1992a.

Dibblee Jr., T. W., Neogene Movements on Calico and Camp Rock Faults,Mojave Desert, California, in Deformation associated with the Neogene Eastern California Shear zone, southeastern California and southwestern Arizona, edited by S. M. Richard, Special Publication 92-1, pp. 24-27, San Bernardino County Museums, San Bernardino, Calif., 1992b.

Dillon, J. T., Geology of the Chocolate and Cargo Muchacho Mountains, southeasternmost California, Ph.D. Dissertation, 405 pp., Univ. Calif., Santa Barbara, Calif., 1975.

Dillon, J. T., G. B. Haxel, and R. M. Tosdal, Structural evidence for northeastward movement on the Chocolate Mountains thrust, southeasternmost California, J. Geophys. Res., 95, 19953-19971, 1990.

Dokka, R. K., Displacements on Late Cenozoic strike-slip faults of the central Mojave Desert, California, Geology, 11, 305-308, 1983.

Dokka, R. K., and C. J. Travis, Late Cenozoic strike-slip faulting in the Mojave Desert, California, Tectonics, 9, 311 340, $1990 \mathrm{a}$.

Dokka, R. K., and C. J. Travis, Role of the eastern California shear zone in accommodating Pacific-North American plate motion, Geophys. Res. Letters, 17, 1323-1326, 1990 b.

Eberly, L. D., and T. B. Stanley Jr., Cenozoic stratigraphy and geologic history of southwestern Arizona, Geol. Soc. Am. Bull., 89, 921-940, 1978.

Frost, E. G.,D. L. Martin, and D. Krummenacher, Mid-Tertiary detachment faulting in southwestern Arizona and southeastern California and its overprint on the Vincent thrust system (abstract), Geol. Soc. Am. Abstr. Prog, 14, no. 4, p. $164,1982$.

Fugro, I., Section 2.5: Geology and Seismology, in Sundesert Nuclear Plant, Early Site Review, , 163 pp., San Diego Gas and Electric Co., San Diego, Calif., 1975.

Fuis, G. S., M. E. Friedman, and J. A. Hileman, Preliminary catalog of earthquakes in southern California, July, 1974September, 1976, Open-file Rep. 81-270, 73 pp., U. S. Geol. Surv., Reston, Virginia, 1977.

Garfunkel, Z., and Ron H., Block rotation and deformation by strike-slip faults 2 . The properties of a type of macroscopic discontinuous deformation, J. Geophys. Res., 90, 8589-8602, 1985.

Goodmacher, J.,L. Barnett,G. Buckner,L. Ouachrif,A. Vidigal, and E. G. Frost, The Clemens Well Fault in the Orocopia Mountains of southern California: a strike-slip or normal fault structure? (abstract), Geol. Soc. Am. Abstr. Prog., 21 , no. 5, p. 85, 1989.

Graham, S. A., R. G. Stanley, J. V. Bent, and J. B. Carter, Oligocene and Miocene paleogeography of central California and displacement along the San Andreas fault, Geol. Soc. Am. Bull., 101, 711-730, 1989.

Grimes, G. J., Geology at the convergence of the Pinto Mountain fault and Morongo Valley fault, southern California, M. S. Thesis, 112 pp., Calif. State Univ., Los Angeles, Calif., 1987.

Grubensky, M. J., and W. C. Bagby, Miocene calc-alkaline magmatism, calderas and crustal extension in the Kofa and Castle Dome Mountains, southwestern Arizona, J. Geophys. Res., 95, 19989-20003, 1990.

Grubensky, M. J., and G. B. Haxel, Geologic map of the Castle Dome 15' Quadrangle, scale 1:62500, U. S. Geol. Surv. , in press.

Hamilton, W., Mesozoic geology and tectonics of the Big Maria Mountains region, southeastern California, in Mesozoic geology of southern Arizona and adjacent areas, edited by W. R. Dickinson et al., Ariz. Geol. Soc. Digest, 18, pp. $33-47,1987$. 
Harding, L. E., and P. J. Coney, The geology of the McCoy Mountains Formation, southeastern California and southwestern Arizona, Geol. Soc. Am. Bull., 96, 755-769, 1985.

Haxel, G. B., The Orocopia Schist and the Chocolate Mountains thrust, Picacho-Peter Kane Mountain area, southeasternmost California, Ph.D. Dissertation, 277 pp., Univ. Calif., Santa Barbara, California, 1977.

Haxel, G. B., J. R. Budahn, T. L. Fries, B. W. King, L. D. White, and P. J. Aruscavage, Geochemistry of the protolith of the Orocopia schist, southeastern California and tectonic inferences, in Mesozoic rocks of southern Arizona and adjacent areas, edited by W. R. Dickinson et al., Ariz. Geol. Soc. Digest, 18, pp. 49-64, 1987.

Haxel, G., and J. Dillon, The Pelona-Orocopia Schist and Vincent-Chocolate Mountain thrust system, southern California, in Mesozoic paleogeography of the western United States, edited by D. G. Howell et al., Paleogeography Symposium 2, pp. 453-469, Soc. Econ. Paleon. Min., Pac. Sec., Los Angeles, Calif., 1978.

Haxel, G. B., and R. M. Tosdal, Significance of the Orocopia Schist and Chocolate Mountains thrust in the late Mesozoic tectonic evolution of the southeastem California-southwestern Arizona region (abstract), in Frontiers in geology and ore deposits of Arizona and the Southwest, edited by B. Beatty and P.A.K. Wilkinson, Ariz. Geol. Soc. Digest, 16, pp. 52-61, 1986.

Haxel, G. B., R. M. Tosdal, and J. T. Dillon, Tectonic setting and lithology of the Winterhaven Formation, a new Mesozoic stratigraphic unit in southeasternmost California and southwestern Arizona, U. S. Geol. Surv. Bulletin 1599, 19 pp., 1985.

Hill, R. T., Southern California geology and Los Angeles earthquakes, 232 pp., Calif. Acad. Sci., Los Angeles, Calif., 1928.

Hope, R. A., Geology and structural setting of the eastern Transverse Ranges, southern California, Ph.D. Dissertation, 201 pp., Univ. Calif., Los Angeles, California, 1966.

Hornafius, J. S., Neogene tectonic rotation of the Santa Ynez Range, western Transverse Ranges, California suggested by paleomagnetic investigation of the Monterey Formation, J. Geophys. Res., 90, 12503-12522, 1985.

Howard, K. A., and C. M. Allen, Geologic map of the southern part of the Dale Lake 15-minute quadrangle, San Bernardino and Riverside Counties, California, scale 1:62500, U. S. Geol. Surv. Open-File Rep. 88-534, Reston, Virginia, 1988.

Howard, K. A., and D. M. Miller, late Cenozoic Faulting at the Boundary between the Mojave and Sonoran Blocks: Bristol Lake Area, California, in Deformation associated with the Neogene Eastern California Shear zone, southeastern California and southwestern Arizona, edited by S. M. Richard, Special Publication 92-1, pp. 37-47, San Bernardino County Museums, San Bernardino, Calif., 1992.

Irwin, W. P., Geology and Plate Tectonic Development, in The San Andreas Fault system, California, edited by R. E. Wallace, U. S. Geol. Surv. Prof. Pap. 1515, pp. 61-80, Denver, Colo., 1990.

Jachens, R. C., and A. Griscom, An isostatic residual gravity map of California--A residual map for interpretation of anomalies from intracrustal sources, in The utility of regional gravity and magnetic anomaly maps, edited by W. J. Hinze, pp. 347-360, Soc. Expl. Geophysicists, Tulsa, Oklahoma, 1985.

Jacobson, C. E., ${ }^{40} \mathrm{Ar}-{ }^{39} \mathrm{Ar}$ geochronology of the Pelona Schist and related rocks, southern California, J. Geophys. Res., 95, 509-528, 1990.

Jagiello, K., J. M. Christie, and R. G. Blom, Horizontal Separation of Major late Cenozoic Strike-slip Faults in the Twentynine Palms Region, Mojave Desert, California, in Deformation associated with the Neogene Eastern California Shear zone, southeastern California and southwestern Arizona, edited by S. M. Richard, Special Publication 92-1, pp. 48-53, San Bernardino County Museums, San Bernardino, Calif., 1992.

Jennings, C. R., Geologic map of California, scale 1:750,000, no. 2, Calif. Div. Mines Geol., , San Francisco, Calif., 1977.

John, B. E., Reconnaissance study of Mesozoic plutonic rocks in the Mojave Desert region, in Tectonic framework of the Mojave and Sonoran Deserts, California and Arizona, edited by K. A. Howard et al., U. S. Geol. Surv. Openfile Report 81-503, 48-50 pp., 1981.

Joseph, S. E., T. E. Davis, and P. L. Ehlig, Strontium isotopic correlation of the La Panza Range Granitic rocks with similar rocks in the central and eastern Transverse Ranges, in Geology and Mineral Wealth of the California Transverse Ranges, edited by D. L. Fife et al., Annual Symposium Field Trip Guidebook, pp. 310-320, S. Coast Geol. Soc., Santa Ana, Calif., 1982.

Larsen, S., and R. Reilinger, Age Constraints for the Present Fault Configuration in the Imperial Valley, California Evidence for Northwestward Propagation of the Gulf of California Rift System, J. Geophys. Res., 96, 1033910346, 1991.

Luyendyk, B. P., Crustal rotation and fault slip in the continental transform zone in southern California, in Paleomagnetic Rotations and Continental Deformation, edited by C. Kissel et al., NATO ASI Series CMathematical and Physical Sciences, 254, pp. 229-246, Kluwer Academic Publishers, Doldrecht, Netherlands, 1989. 
MacFadden, B. J., C. C. Swisher III, N. D. Opdyke, and M. O. Woodburne, Palcomagnetism, geochronology, and possible tectonic rotation of the middle Miocene Barstow Formation, Mojave Desert, southern California, Geol. Soc. Am. Bull., 102, 478-493, 1990.

Mariano, J., M. G. Helferty, and T. B. Gage, Bouguer and isostatic residual gravity maps of the Colorado River region, including the Kingman, Needles, Salton Sea, and El Centro Quadrangles, scale 1:250000, U. S. Geol. Surv. Open-File Rep. 86-347, 7 sheets, 1986.

Matti, J. C., and D. M. Morton, Paleogeographic evolution of the San Andreas fault in southem California: a reconstruction based on a new cross-fault correlation, in The San Andreas fault system; Displacement, palinspastic reconstruction and geologic evolution, edited by R. E. Powell et al., Geol. Soc. Am. Mem. 178, Boulder, Colo., in press.

May, D., Amalgamation of metamorphic terranes in the southeastern San Gabriel Mountains, California, Ph.D. Dissertation, 231 pp., Univ. of California, Santa Barbara, California, 1986.

McCulloch, D. S., Evolution of the offshore central California margin, in The Eastern Pacific Ocean and Hawaii, edited by E. L. Winterer et al., The Geology of North America, N, pp. 439-470, Geol. Soc. Am., Boulder, Colo., 1989.

McJunken, R. C., Strong-motion data for the Homestead Valley earthquake swarm, San Bernardino County, California, 15 March 1979, Calif. Geol., 32, 11-13, 1980.

Meisling, K. E., and R. J. Weldon, Late Cenozoic tectonics of the northwestern San Bernardino Mountains, southern California, Geol. Soc. Am. Bull., 101, 106-128, 1989.

Metzger, D. G., O. J. Loeltz, and B. Irelan, Geohydrology of the Parker-Blythe-Cibola area, Arizona and Califomia, U. S. Geol. Surv. Prof. Pap. 486-G, 130 pp., Reston, Virginia, 1973.

Miller, D. M., and K. A. Howard, Bedrock geologic map of the Iron Mountains quadrangle, San Bernardino and Riverside counties, California, scale 1:62500, US Geol. Surv. Misc. Field Inv. Map MF-1736, Reston, Virginia, 1985.

Miller, S. T., Geology and mammalian biostratigraphy of a part of the northern Cady Mountains, Mojave Desert, California, U. S. Geol. Surv. Open-File Rep. 80-878, 122 pp., Reston, Virginia, 1980.

Miller, W. J., Geology of the Palm Springs-Blythe strip, Riverside County, California, Calif., Quarterly Chapter of the State Mineralogist's Report, 40, pp. 11-72, 1944.

Murray, K. S., J. W. Bell, B. M. Crowe, and D. G. Miller, Geologic structure of the Chocolate Mountains region, southeastern California, in Geology and mineral wealth of the California desert, edited by D. L. Fife et al., pp. 221-223, South Coast Geological Society, Santa Ana, Calif., 1980.

Nielson, J. E., D. R. Lux, G. B. Dalrymple, and A. F. Glazner, Age of the Peach Springs Tuff, southeastern California and westem Arizona, J. Geophys. Res., 95, 571-580, 1990.

ODay, P. A., and J. D. Sims, Sandstone composition and paleogeography of the Temblor Formation, central California-Evidence of early to middle Miocene right lateral displacement on the San Andreas fault system (abstract), Geol. Soc. Am. Abstr. Prog., 18, pp. 165, 1986.

Olmstead, F. H., O. J. Loeltz, and B. Irelan, Geohydrology of the Yuma area, Arizona and California, U. S. Geol. Surv. Prof. Pap. 486-H, 227 pp., 1973.

Powell, R. E., The Chiriaco fault: a left-lateral strike-slip fault in the eastern Transverse Ranges, Riverside County, California (abstract), Geol. Soc. Am. Abstr. Prog., 7, no. 3, p. 362, 1975.

Powell, R. E., Geology of the crystalline basement complex, eastern Transverse Ranges, California: constraints on regional tectonic interpretations, Ph.D. Dissertation, 441 pp., Calif. Inst. Tech., Pasadena, Calif., 1981a.

Powell, R. E., Geology of the Crystalline basement complex, eastern Transverse Ranges, southern California: constraints on regional tectonic interpretation, in Tectonic framework of the Mojave and Sonoran Deserts, California and Arizona, edited by K. A. Howard et al., U. S. Geol. Surv. Open-File Rep. 81-503, pp. 87-89, 1981 b.

Powell, R. E., Crystalline basement terranes in the southern eastern Transverse Ranges, California, in Geologic excursions in the Transverse Ranges, compiled by J. D. Cooper, 78th annual meeting, Cordilleran Section, Field Trip Guidebook, pp. 109-136, Geol. Soc. Am., Boulder, Colo., 1982.

Powell, R. E., Palinspastic reconstruction of crystalline-rock assemblages in southern California (abstract), Geol. Soc. Am. Abstr. Prog., 18, no. 2, p. 172, 1986.

Powell, R. E., and R. J. Weldon II, Evolution of the San Andreas Fault, Ann. Rev. Earth Plan. Sci., 20, 431-468, 1992.

Reynolds, S. J., Geologic map of Arizona, scale 1:1000000, Map 26, 1 sheet, Ariz. Geol. Surv., Tucson, Ariz., 1988.

Richard, S. M., The Chocolate Mountains Anticlinorium in the Middle Mountains, SW Arizona (abstract), Geol. Soc. Am. Abstr. Prog., 21, pp. A64, 1989.

Richard, S. M., Bedrock geologic map of the Imperial Reservoir Quadrangle, Yuma County, Arizona and Imperial County, California, scale 1:24000, Ariz. Geol. Sur. Open-file Rep., Tucson, Ariz., in press.

Richard, S. M., Geologic map of the Red Hill NE Quadrangle, Yuma County, Arizona, scale 1:24000, Ariz. Geol. Sur. Open-file Rep., Tucson, Ariz., in press. 
Richard, S. M., Geologic Map of the Red Hill Quadrangle, Yuma County, Arizona, scale 1:24000, Ariz. Geol. Sur. Open-file Rep., Tucson, Ariz., in press.

Richard, S. M., and R. K. Dokka, Geology of the Packard Well Fault zone, Southeastem California, in Deformation associated with the Neogene Eastern California Shear zone, southeastern California and southwestern Arizona, edited by S. M. Richard, Special Publication 92-1, pp. 71-74, San Bernardino County Museums, San Bernardino, Calif., 1992.

Richard, S. M., and G. B. Haxel, Progressive exhumation of the Orocopia and Pelona Schists along a composite normal fault system, sotheastern California and southwestern Arizona (abstract), Geol. Soc. Am. Abstr. Prog, 23, pp. 92, 1991.

Richard, S. M., and D. R. Sherrod, Introduction to stratigraphy of the area south of I-10, Arizona and Califomia, in Tertiary stratigraphy of the highly extended terranes, California, Arizona, and Nevada, edited by D. R. Sherrod et al., U. S. Geol. Surv. Bull., in press.

Richard, S. M., D. R. Sherrod, and R. M. Tosdal, Cibola Pass Fault, Southwestern Arizona, in Deformation associated with the Neogene Eastern California Shear zone, southeastern California and southwestern Arizona, edited by S. M. Richard, Special Publication 92-1, pp. 66-70, San Bernardino County Museums, San Bernardino, Calif., 1992.

Ross, T. M., B. P. Luyendyk, and R. B. Haston, Paleomagnetic evidence for Neogene clockwise tectonic rotations in the central Mojave Desert, California, Geology, 17, 470-473, 1989.

Rotstein, Y., J. Combs, and S. Biehler, Gravity investigation in the southeastern Mojave Desert, California, Geol. Soc. Am. Bull., 87, 981-993, 1976.

Sedlock, R. L., and D. H. Hamilton, Late Cenozoic tectonic evolution of southwestern California, J. Geophys. Res., 96, 2325-2351, 1991.

Sherrod, D. R., L. G. Pickthorn,R. M. Tosdal,M. J. Grubensky, and R. D. Koch, Major Early Miocene extensional deformation in southwestern Arizona and southeastern California (abstract), Geol. Soc. Am. Abstr. Prog, 19, no. 7, p. 841, 1987.

Sherrod, D. R., and R. M. Tosdal, Geologic Setting and Tertiary Structural Evolution of Southwestern Arizona and Southeastern California, J. Geophys. Res., 96, 12407-12423, 1991.

Silver, L. T., T. H. Anderson, C. M. Conway, J. D. Murray, and R. E. Powell, Geological features of southwestern North America, in Skylab explores the Earth NASA SP-380, pp. 89-135, Nat. Aeronautics Space Admin., Washington D. C., 1977.

Smith, D. P., San Juan-St. Francis fault-hypothesized major middle Tertiary right-lateral fault in central and southern California, Calif. Div. Mines Geol. Special Report 129, pp. 41-50, Sacramento, Calif., 1977.

Spencer, J. E., Late Cenozoic extensional and compressional tectonism in the southern and western Avawatz Mountains, southeastem California, in Basin and Range extensional tectonics near the latitude of Las Vegas, Nevada, edited by B. P. Wernicke, Geol. Soc. Am. Memoir 176, pp. 317-333, Boulder, Colo., 1990.

Spencer, J. E., and S. J. Reynolds, Middle Tertiary tectonics of Arizona and adjacent areas, in Geologic Evolution of Arizona, edited by J. P. Jenney et al., Ariz. Geol. Soc. Digest 17, pp. 539-574, Tucson, 1989.

Stock, J. M., and K. V. Hodges, Pre-Pliocene extension around the Gulf of California and the transfer of Baja California to the Pacific Plate, Tectonics, 8, 99-115, 1989.

Stock, J., and P. Molnar, Uncertainties and Implications of the Late Cretaceous and Tertiary Position of North America Relative to the Farallon, Kula, and Pacific Plates, Tectonics, 7, 1399-1384, 1988.

Stone, P., Preliminary Geologic map of the Blythe $30^{\prime}$ by $60^{\prime}$ quadrangle, California and Arizona, scale 1:100000, U. S. Geol. Surv. Open-File Rep., 90-497, Denver, Colo., 1990.

Stone, P., and M. M. Kelly, Geologic map of the Palen Pass Quadrangle, Riverside County, California, scale 1:24000, US Geol. Surv. Misc. Field Inv. Map MF-2070, 1989.

Stone, P., V. M. Page, W. Hamilton, and K. A. Howard, Cretaceous age of the McCoy Mountains Formation, southeastern California and southeastern Arizona, Geology, 15, 561-564, 1987.

Stone, P., and G. J. Pelka, Geologic map of the Palen-McCoy Wilderness Study Area and vicinity, Riverside County, California, scale 1:62500, US Geol. Surv. Misc. Field Inv. Map 2092, 1989.

Tennyson, M. E., Pre-transform early Miocene extension in western Califomia, Geology, 17, 792-796, 1989.

Terres, R. R., Paleomagnetism and tectonics of the central and eastem Transverse Ranges, southern California, Ph.D. Dissertation, 323 pp., Univ. Calif., Santa Barbara, Calif., 1983.

Tosdal, R. M., Mesozoic rock units along the Late Cretaceous Mule Mountains thrust system, southeastern California and southwestern Arizona, Ph.D. Dissertation, 365 pp., Univ. Calif., Santa Barbara, Calif., 1988.

Tosdal, R. M., Jurassic low-angle ductile shear zones, SE California and SW Arizona: Thrust faults, extensional faults or rotated high-angle faults? (abstract), Geol. Soc. Am. Abstr. Prog., 22, pp. 89, 1990. 
Tosdal, R. M., G. B. Haxel, and J. E. Wright, Jurassic geology of the Sonoran Desert region, southern Arizona, southeast California, and northernmost Sonora: Construction of a continental-margin magmatic arc, in Summary of Arizona Geology, edited by J.P. Jenny et al., Ariz. Geol. Soc. Digest, 17, pp. 397-434, 1989.

Tosdal, R. M., and D. R. Sherrod, Geometry of Miocene extensional deformation lower Colorado River region, southeastern California and southwest Arizona: Evidence for the presence of a regional low-angle normal fault in Papers presented to the Conference on Heat and Detachment in Crustal Extension on Continents and Planets, pp. 147-151, Lunar Plan. Inst., Houston, Texas, 1985.

Veseth, M. K., Paleomagnetics of Mid-Tertiary and younger volcanic rocks of the Kofa Mountains, southeastem Arizona, M. S. thesis, 168 pp., San Diego State Univ., San Diego, Calif., 1985.

Wells, R. E., and J. W. Hillhouse, Paleomagnetism and tectonic rotation of the lower Miocene Peach Springs TuffColorado Plateau, Arizona, to Barstow, California, Geol. Soc. Am. Bull., 101, 846-863, 1989.

Wernicke, B., and B. C. Burchfiel, Modes of extensional tectonics, J. Structural Geol., 4, 105-115, 1982.

Williams, P. L., L. R. Sykes, C. Nicholson, and L. Seeber, Seismotectonics of the easternmost Transverse Ranges, California: Relevance for seismic potential of the southern San Andreas fault, Tectonics, 9, 185-204, 1990.

Young, R. A., and W. J. Brennan, Peach Springs Tuff: Its bearing on structural evolution of the Colorado Plateau and development of Cenozoic drainage in Mohave County, Arizona, Geol. Soc. Am. Bull., 85, 83-90, 1974. 


\section{FIGURE CAPTIONS}

Figure 1. Regional location map. Abbreviations are as follows: MD-Mojave Desert; ECSZ-eastern California shear zone; MFTB-Maria Fold and thrust belt; WDF-Whipple Detachment fault system; CMA-Chocolate Mountains Anticlinorium; SGF-San Gabriel fault; SAF-San Andreas Fault; ETR-eastern Transverse Ranges.

Figure 2. Reconstruction base map, showing fault array deduced from gravity and geologic maps. Locations of known or suspected faults in Little Chuckwalla and western Chocolate Mountains area are indicated schematically (based on interpretation of Landsat satellite imagery, geologic reconnaissance, Murray et al. [1980], and Powell [1981a]). Other sources are listed in Table 1; abbreviations for fault names are keyed to Table 1. Diagonal ruling indicates location of negative gravity anomalies greater than $25 \mathrm{mgal}$ from Mariano et al. [1986].

Figure 3. Map showing location of geographic features referred to in text.

Figure 4. Generalized geologic map of the region NE of the San Andreas Fault in southeastern California and adjacent Arizona. Data from Calzia et al. [1986]; Crowell [1975]; Dillon [1975]; Murray et al. [1980]; Powell [1981a, 1982]; Reynolds [1988]; and Stone and Pelka [1989].

Figure 5. Geologic map of Palen Pass area. Generalized from Stone and Pelka [1989]. Dashed fault cutting basalt in west-central part of map is inferred from change in elevation of the base of the basalt and breccia units, and projection of a fault mapped in pre-Tertiary rocks by Stone and Pelka [1989].

Figure 6. Paleomagnetic data from the lower Colorado River region. Data are site means; secular variation has not been averaged. Sources are indicated by the numbers in parenthesis: (1) Costello [1985]; (2) Veseth [1985]; (3) Butterworth [1984]; (4) Calderone and Butler [1984]; (5) Callian [1984].

Figure 7a. Palinspastic reconstruction of southeastern California and adjacent Arizona for middle Miocene time. Shaded areas are present mountain range blocks shown in Figures 1 and 2. Dashed lines outline blocks bounded by faults shown in Figure 2.

Figure $7 \mathrm{~b}$. Pliocene configuration of blocks indicated in figure 7a. Gaps indicate regions that have undergone extension. Overlaps indicate regions that have undergone contraction. Overlaps in the Cibola fault area and eastem Chocolate Mountains are largely due to reconstruction of distributed deformation using a few discrete faults. Quaternary deformation in the Pinto Mountains area has been reconstructed as discussed in the text.

Figure 8. Geologic map of the Chocolate Mountains-Castle Dome Mountains region. Compiled from Dillon [1975]; Haxel [1977]; Sherrod and Tosdal [1991]; Richard [in press and unpublished data]; and Grubensky and Haxel [in press].

Figure 9. Generalized structures along the Chocolate Mountains anticlinorium

Figure 10. Distribution of major ash flow tuffs in SW Arizona. Data from Grubensky and Bagby [1990], Sherrod and Tosdal [1991], and Richard [in press and unpublished].

Figure 11. a) Geography and faults in the Twentynine Palms area. Numbers indicate the location of offset markers across Pinto Mountain fault (see Table 1) b) Trigonometry of relationships at intersection of the Mojave Desert and Eastern Transverse Range domains. c) Abstract block geometry and reconstruction of slip on faults between Copper Mountain and the Sheep Hole fault. The actual fault pattern is much more complex with transfer of slip between curviplanar faults. Only east-trending faults in the eastern part of the eastern Transverse Ranges are shown here. The heavy lines indicate faults active during two stages of rotation, first rotating $24^{\circ}$ while all faults are active, followed by $15^{\circ}$ rotation while only the Blue Cut, Ivanhoe and Pinto Mountain faults are active. Note that the Sheep Hole fault terminates at its original intersection with the Pinto Mountain fault, and after $39^{\circ}$ of rotation about $3.5 \mathrm{~km}$ of left slip accumulate north of the final intersection.

Figure 12. Sketch reconstruction of Southeastern California at $10 \mathrm{Ma}$. A clockwise rotation of $10^{\circ}$ of the San Gabriel block has been reconstructed. Slip on the Squaw Peak thrust [Meisling and Weldon, 1989] is very poorly constrained; the gap between the San Bernardino Mountains and Pinto Mountains could be due in part to unreconstructed rotation of the San Bernardino Mountains and slip on NW-trending right slip faults. The hatched double line indicates the northem boundary of thick Tertiary volcanic and sedimentary rocks as in Figure 10. Abbreviations for geographic localities, tectonic blocks and faults: MP-Mount Pinos; FM-Frazier Mountain; BB--Banning Block; CB--Cucamonga block; LM-Liebre Mountain; SG--San Gabriel Mountains; SFF-San Francisquito fault; FF-Fenner Fault; CWF-Clemens Well fault. Map based on reconstruction of Figure 7b, and reconstructions by May [1986], Powell and Weldon [1992], and Matti and Morton [in press]. Geologic data from these sources and sources listed for Figure 4. 


\section{TABLES}

Table 2. Parameters describing geometry of rotation in the eastem Transverse Ranges. Slip and width are in $\mathbf{k m}$. Estimated errors: fault strike: $\pm 3^{\circ}$ (based on the curvature of the faults); domain width and slip: $\pm 10 \%$. Based on measurements from Bishop [1964] and Bortugno and Spittler [1986].

Table 2a. Measured orientation, slip and width of domains. Southern only domains includes faults south of the Blue Cut fault within the eastern Transverse Ranges.

\begin{tabular}{|c|c|c|c|c|}
\hline Domain & fault strike $\left({ }^{\circ}\right)$ & min slip & max slip & width \\
\hline \multicolumn{5}{|l|}{ al } \\
\hline$E-W$ & 89 & 30.5 & 33.0 & 67.0 \\
\hline NW & 143 & 30.4 & 57.9 & 41.7 \\
\hline \multicolumn{5}{|c|}{ southern only } \\
\hline NW & 153 & 30.4 & 57.9 & 39.3 \\
\hline EW & 87 & 20.5 & 21.0 & 47.0 \\
\hline
\end{tabular}

Table 2b. Calculated rotation and slip. Total slip for NW-trending faults does not include slip on the Sheep Hole fault. First part of the table shows calculated rotations necessary to match the minimum and maximum slip criteria listed in Table 2a for slip on the EW faults in the eastern Transverse Ranges, and the NW trending faults north of the Pinto Mountain fault (criteria shown in bold). Slip on other fault systems is calculated based on the rotation necessary to meet the slip criteria. Values that do not match the geologic estimates are underlined. The best fit is obtained if the eastern boundary of the domain south of the Blue Cut fault rotates $15^{\circ}$ clockwise after $24^{\circ}$ of clockwise rotation accommodated by all faults in the domain.

\begin{tabular}{|c|c|c|c|c|c|}
\hline total rotation & rigid component & EW slip & NW slip & PMF slip & SH slip \\
\hline \multicolumn{6}{|c|}{ eastem boundary fixed: } \\
\hline 22.8 & 0 & 33.0 & 18.3 & 8.7 & 14.0 \\
\hline 20.8 & 0 & 30.5 & 16.9 & 8.3 & 13.4 \\
\hline 71.0 & 0 & 97.4 & 53.4 & 3.4 & 5.7 \\
\hline 41.1 & 0 & 511 & 30.4 & 11.2 & 18.9 \\
\hline \multicolumn{6}{|c|}{ eastern boundary rotates: } \\
\hline 39 & 15 & 21.0 & 29.0 & 9.8 & 4.2 \\
\hline
\end{tabular}




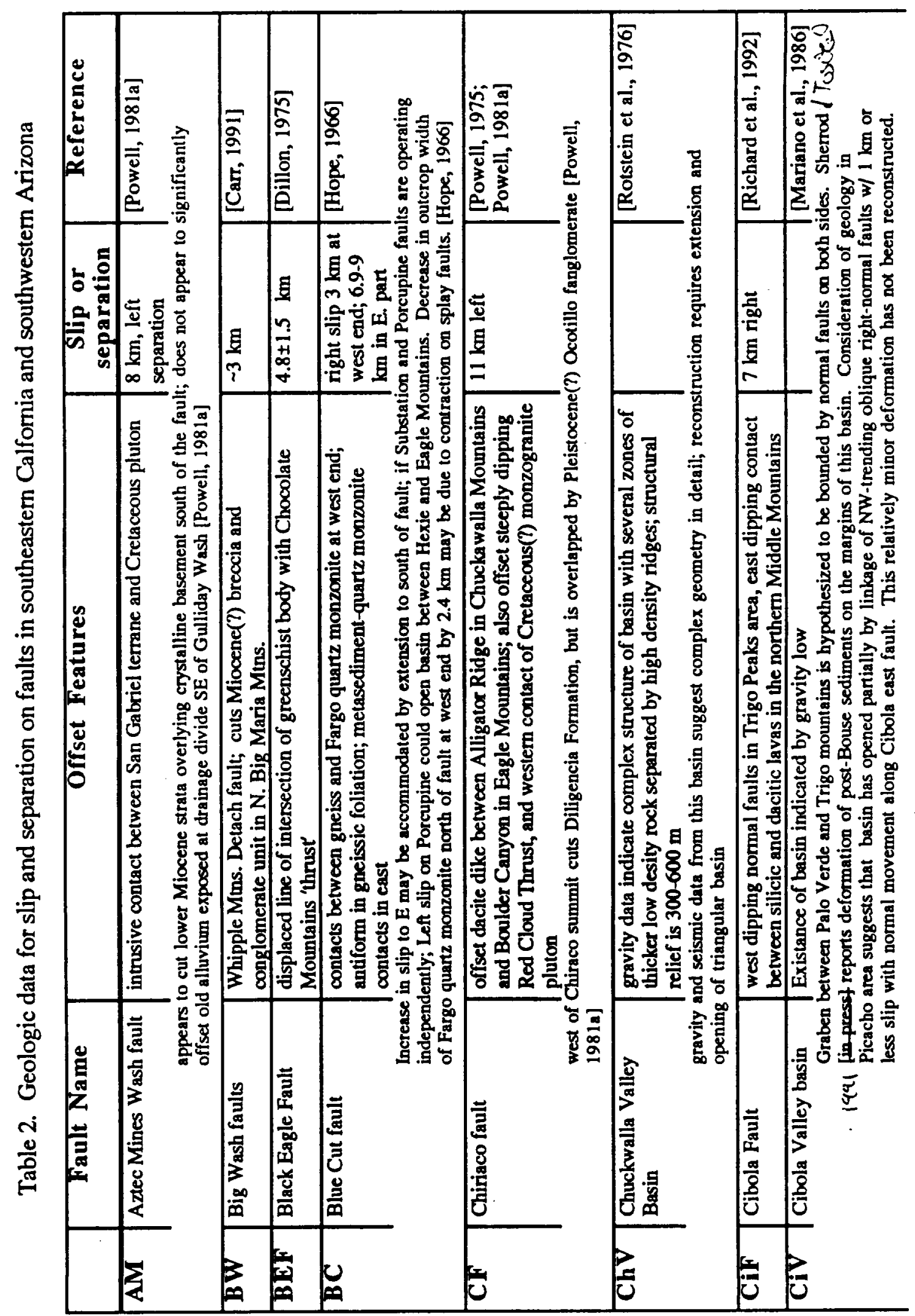

PRECEDING MAGE BLANK NU: FILNAL 


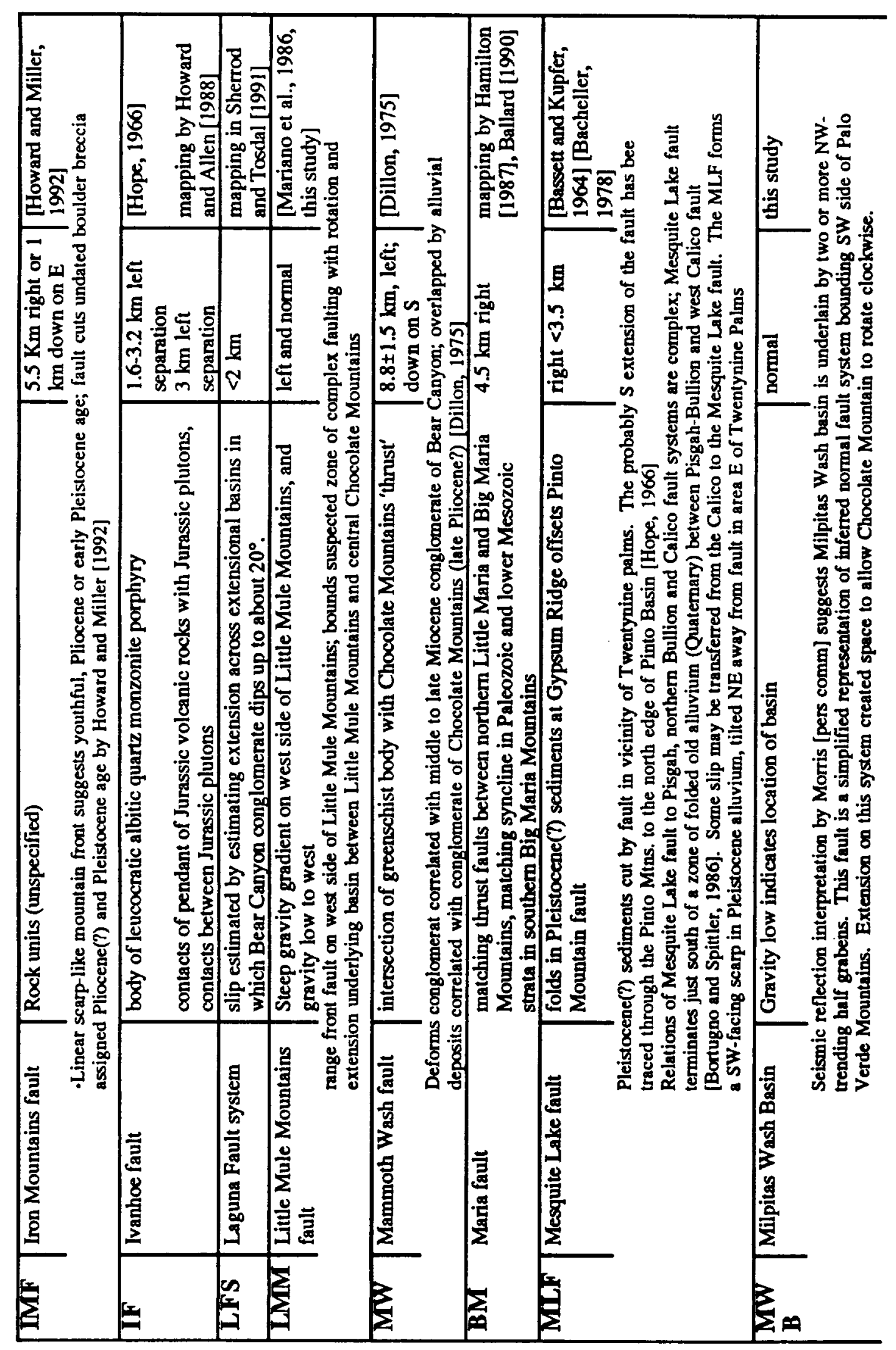




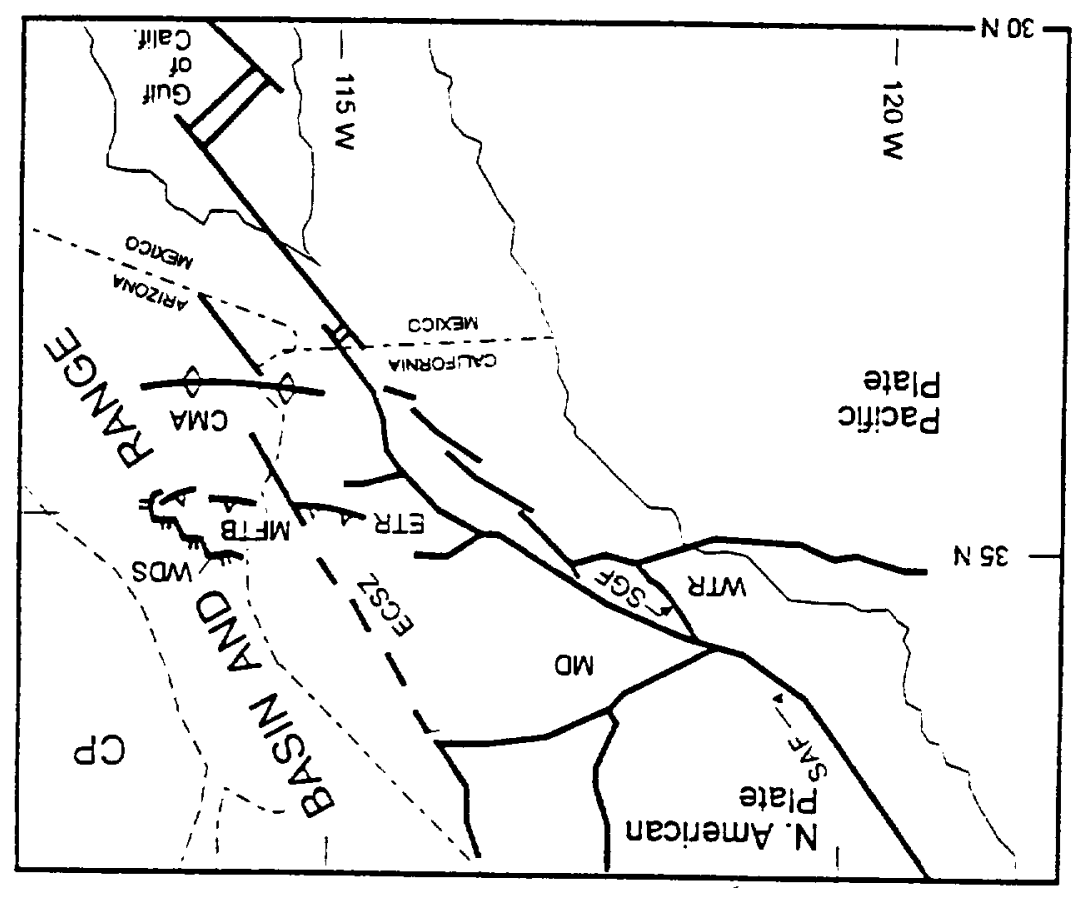




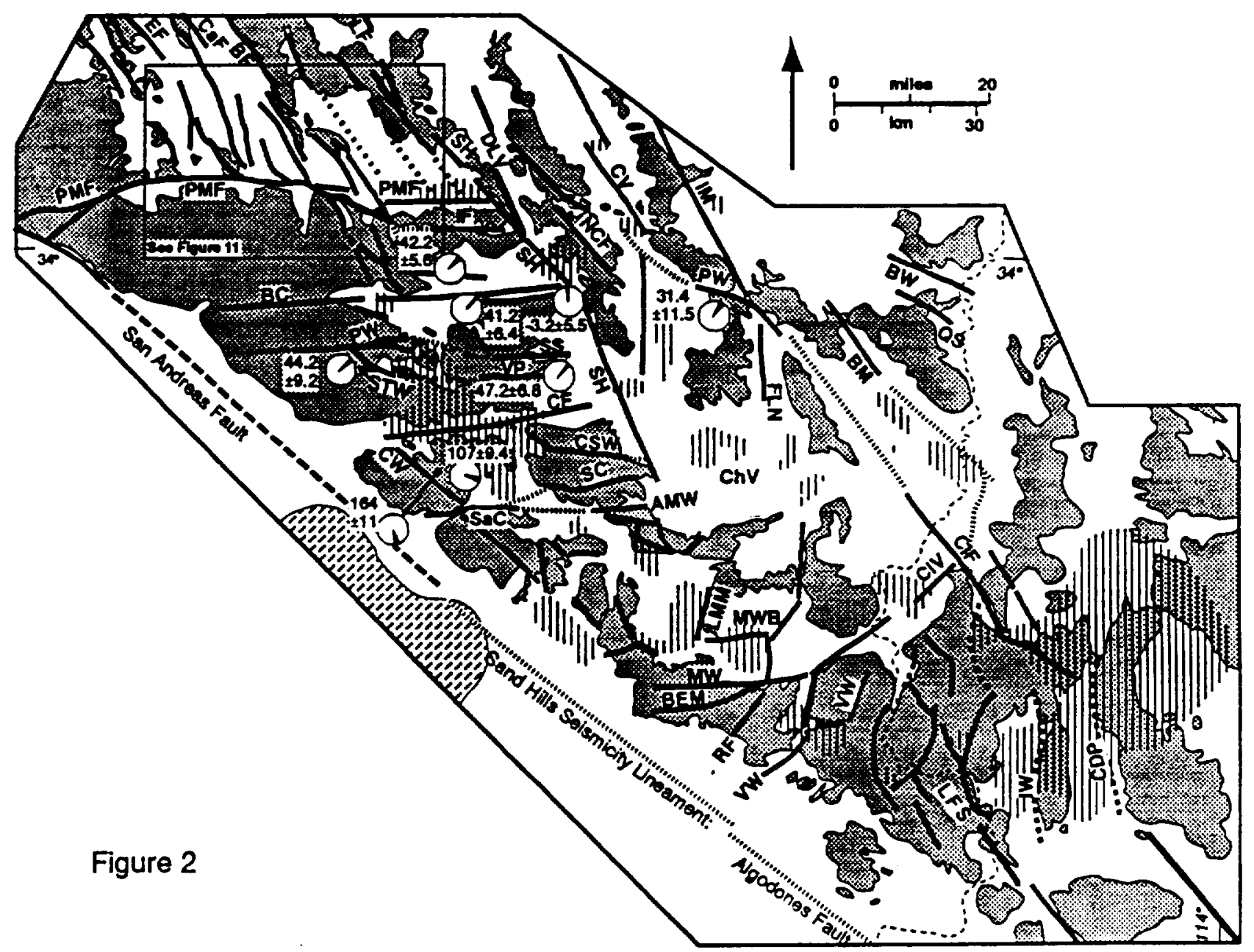




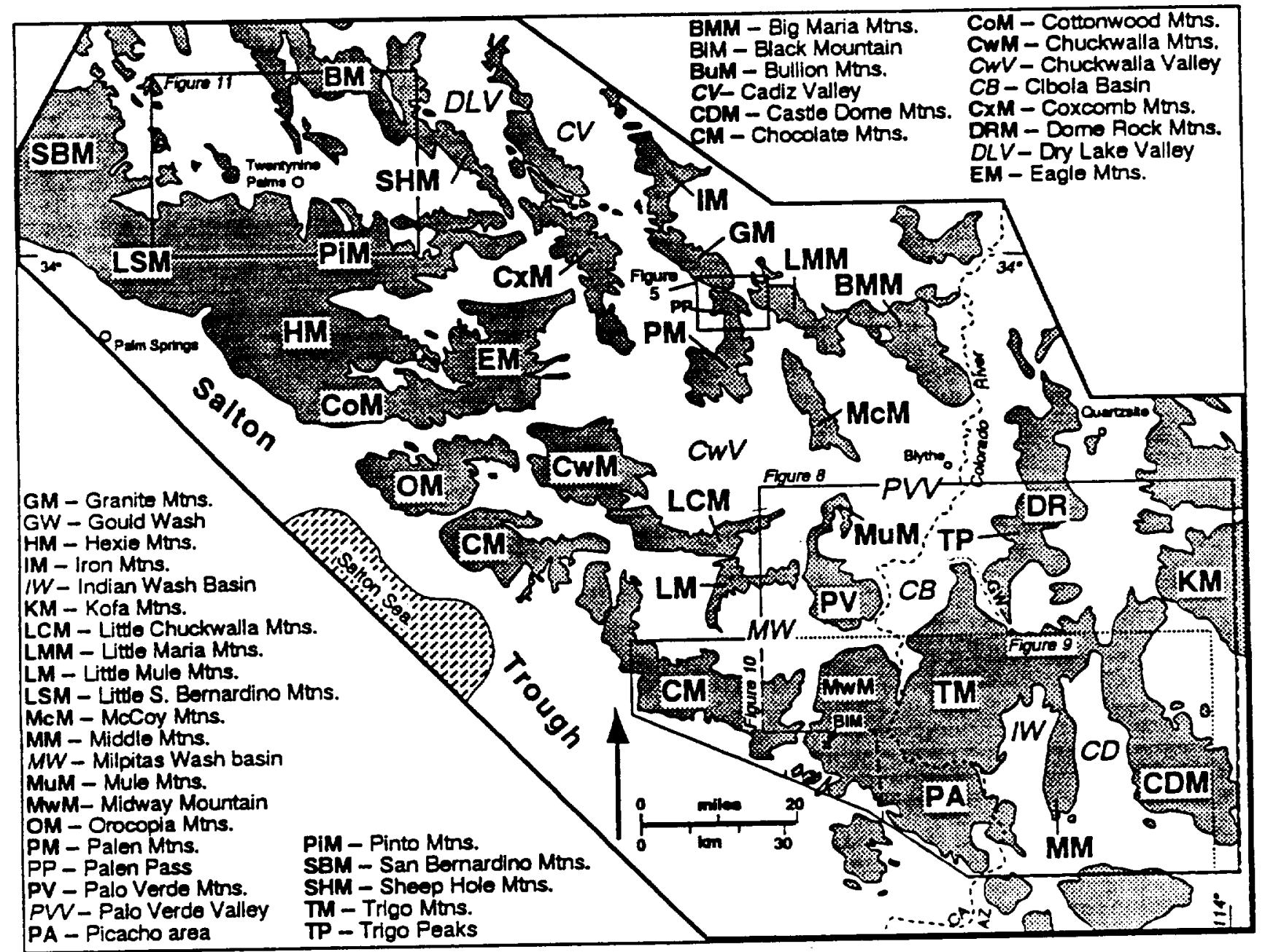

Figure 3. Locations referred to in text 

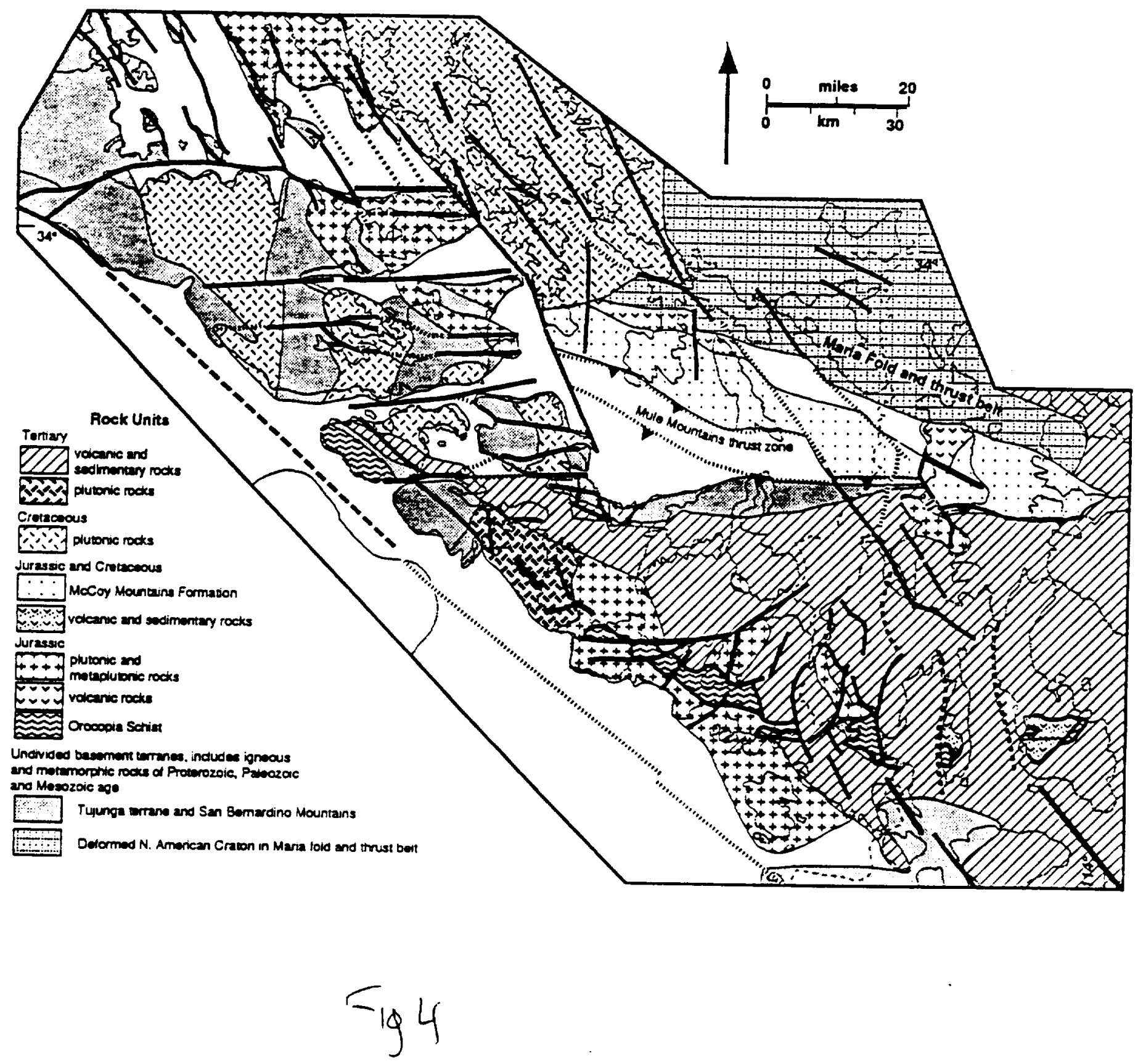

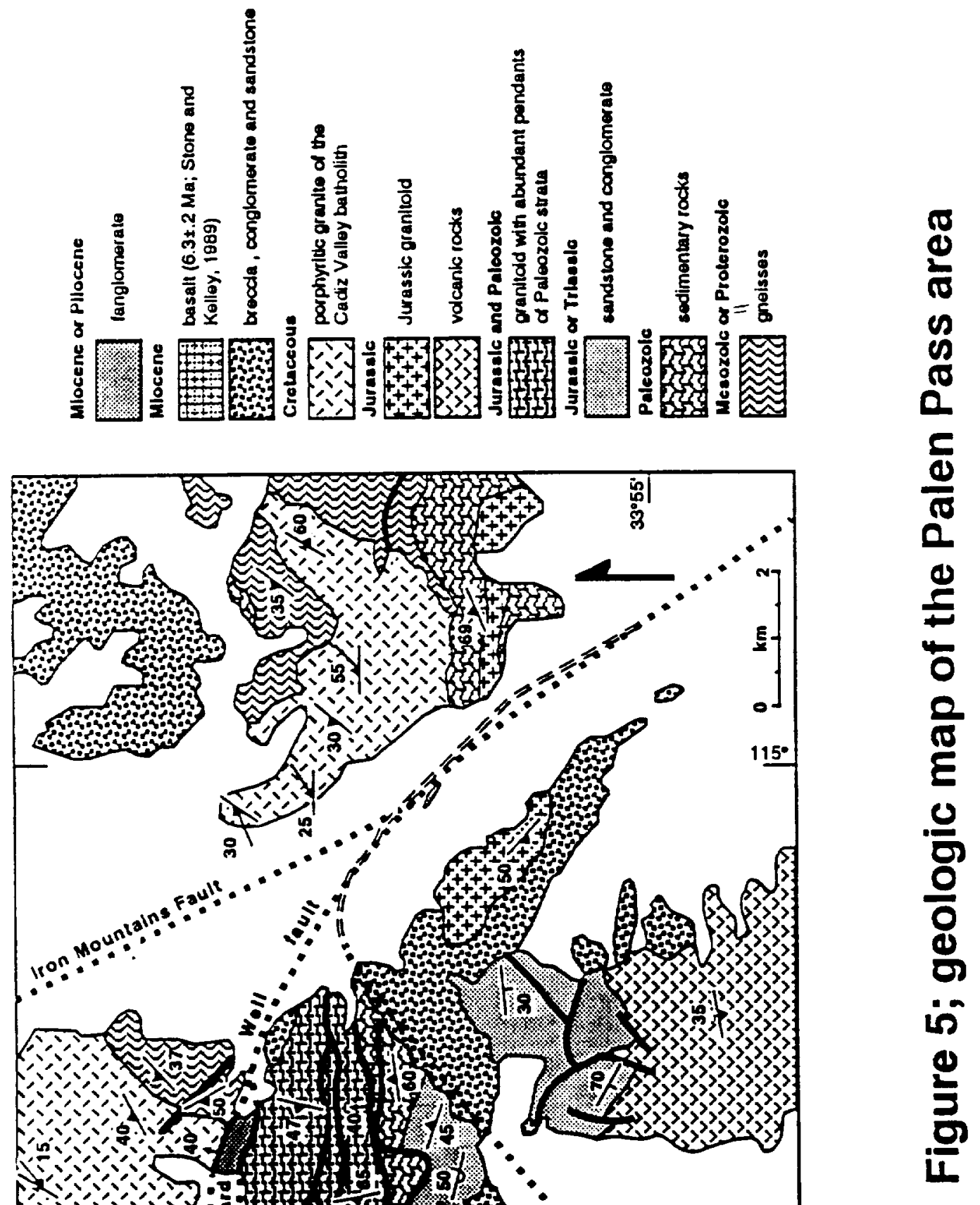


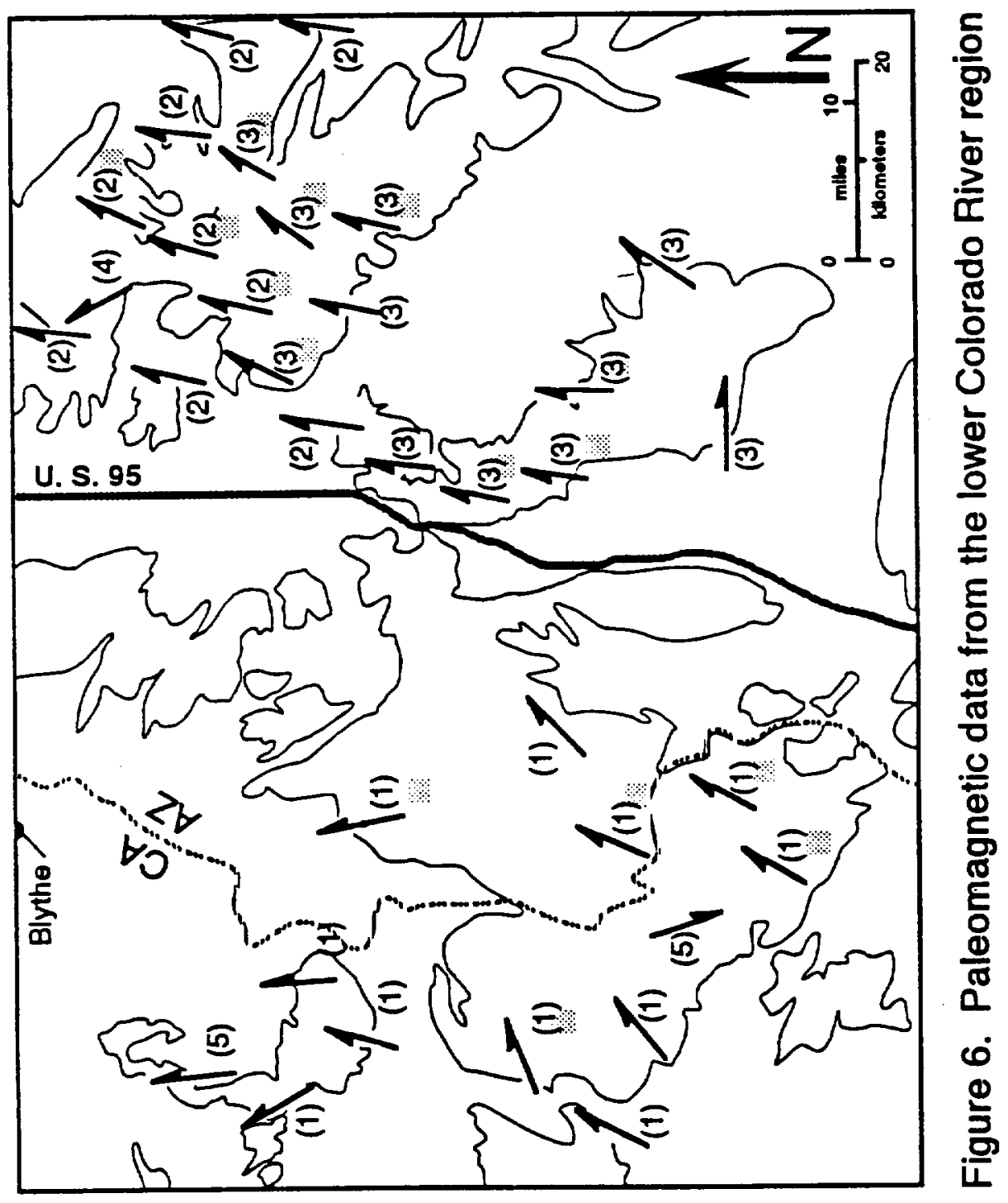




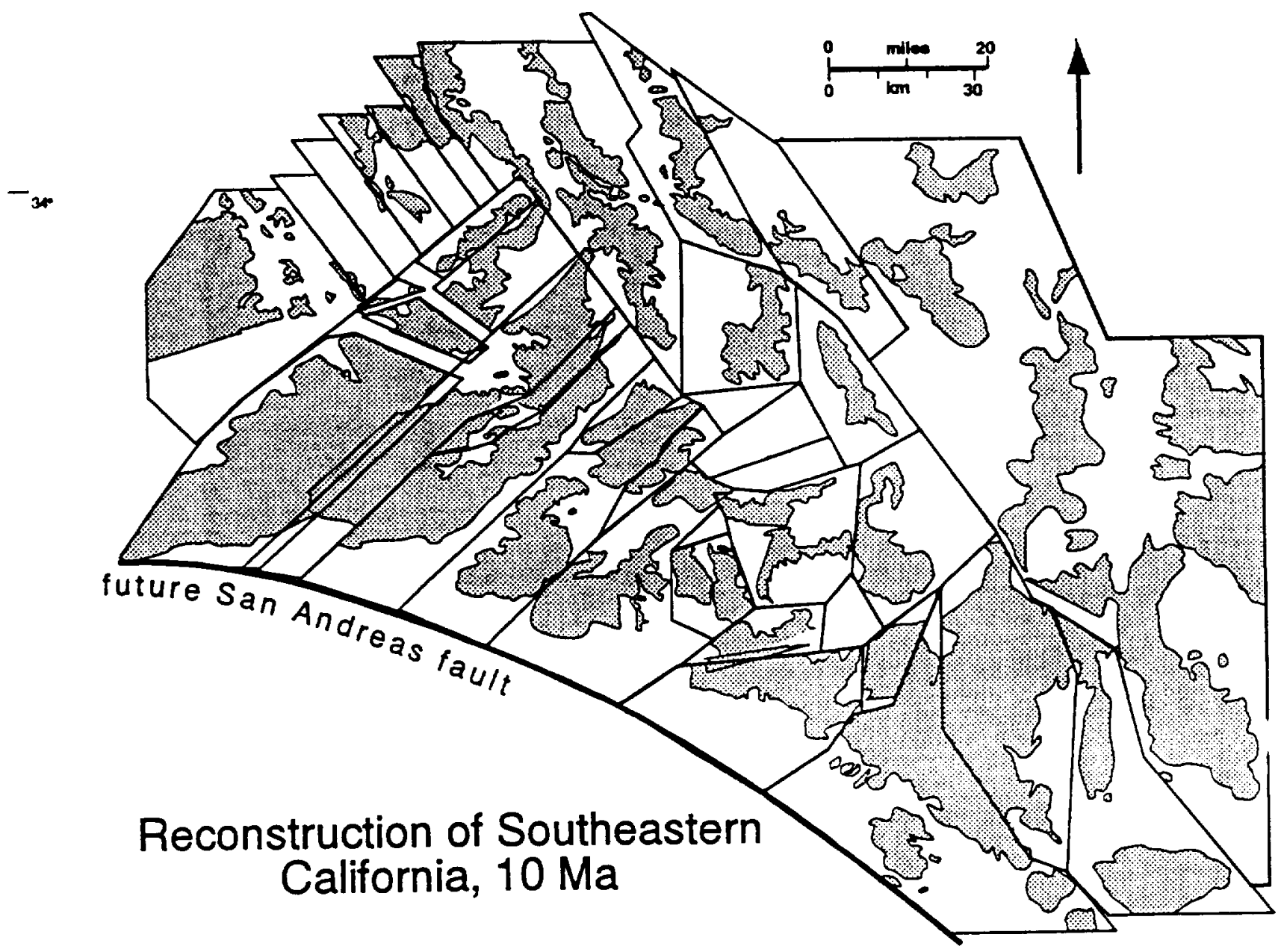

Figure $7 a$.

S. M. Richard \$/1992 


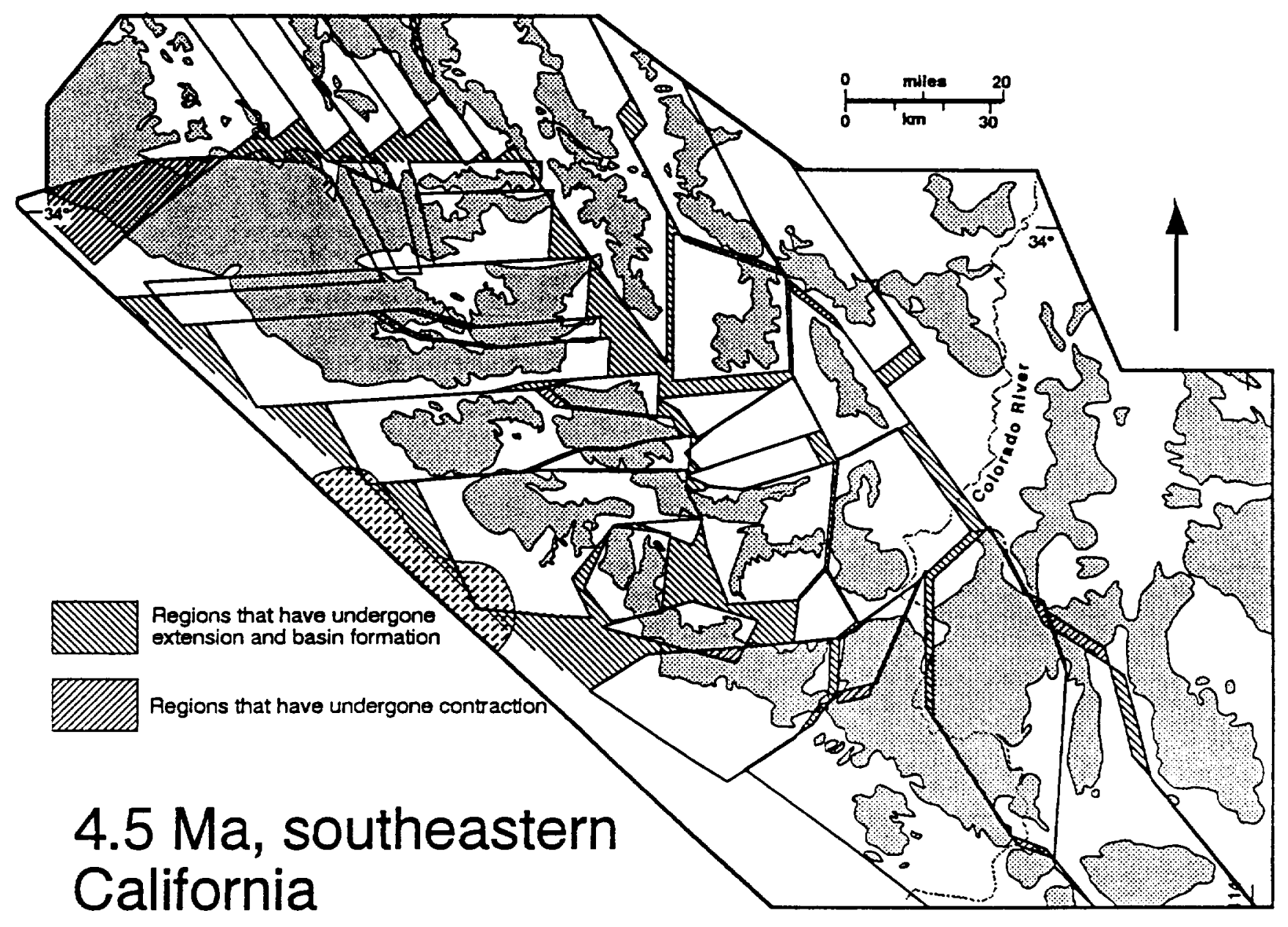

Figure $7 \mathrm{~b}$.

S. M. Pichard 9/1992 


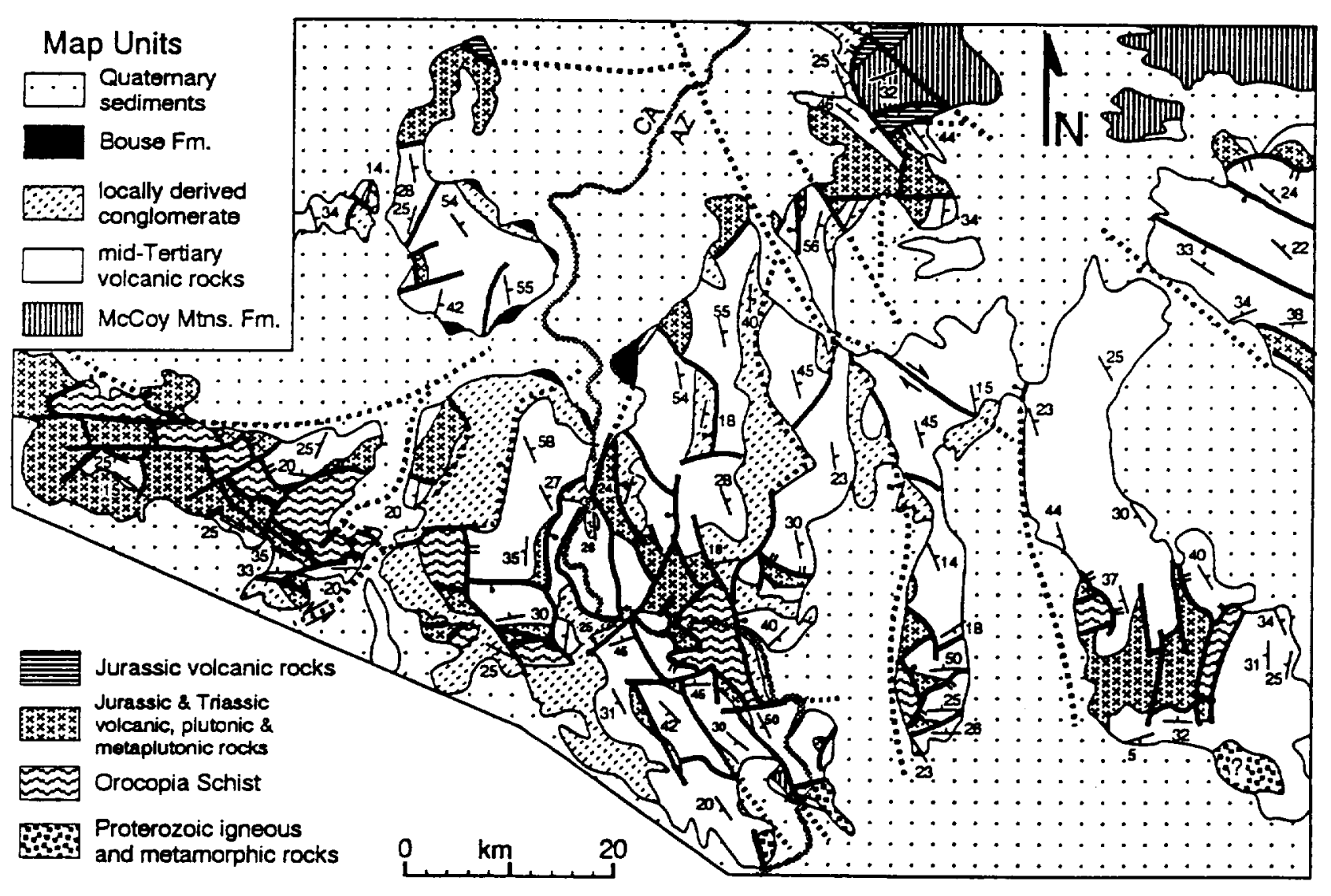




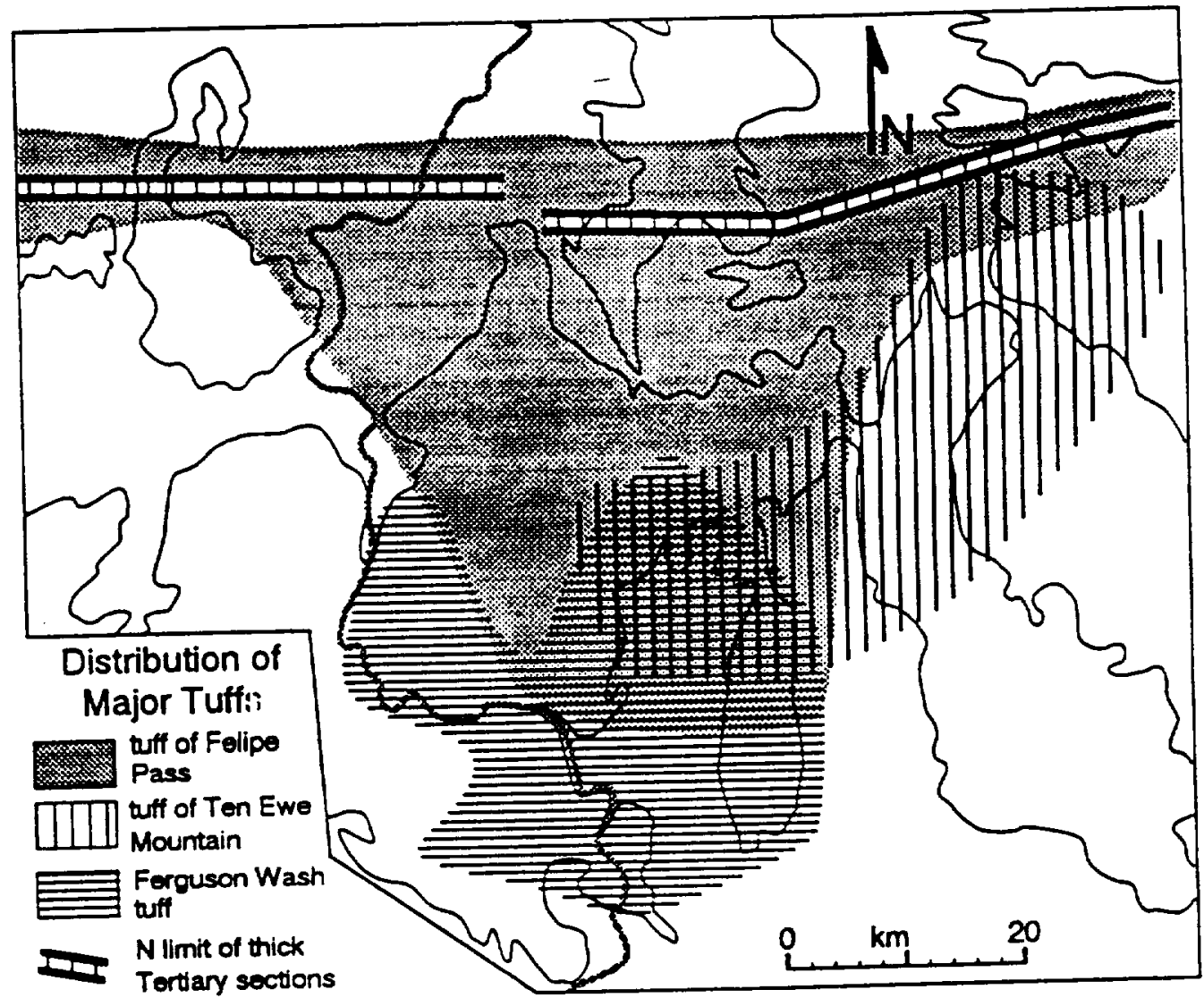

Fig 10 


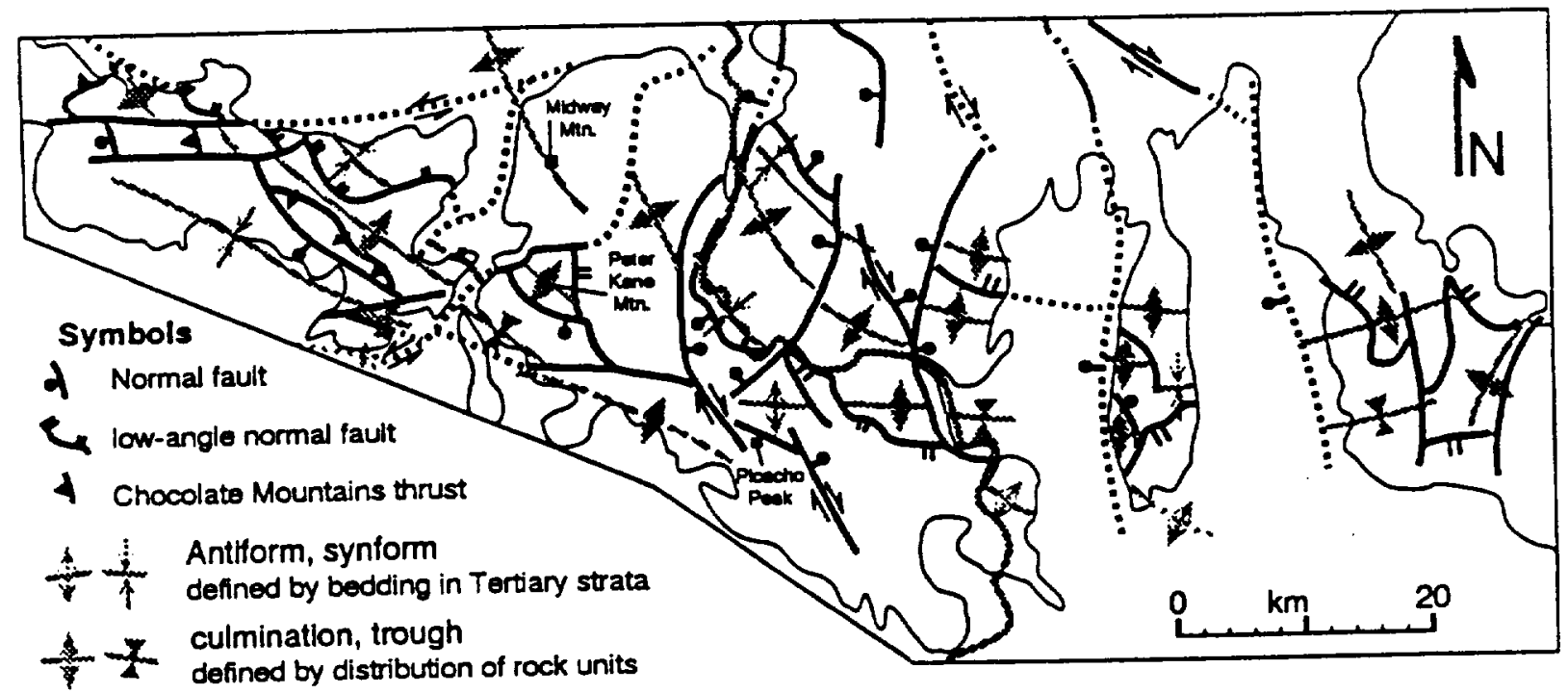

Fig 9 

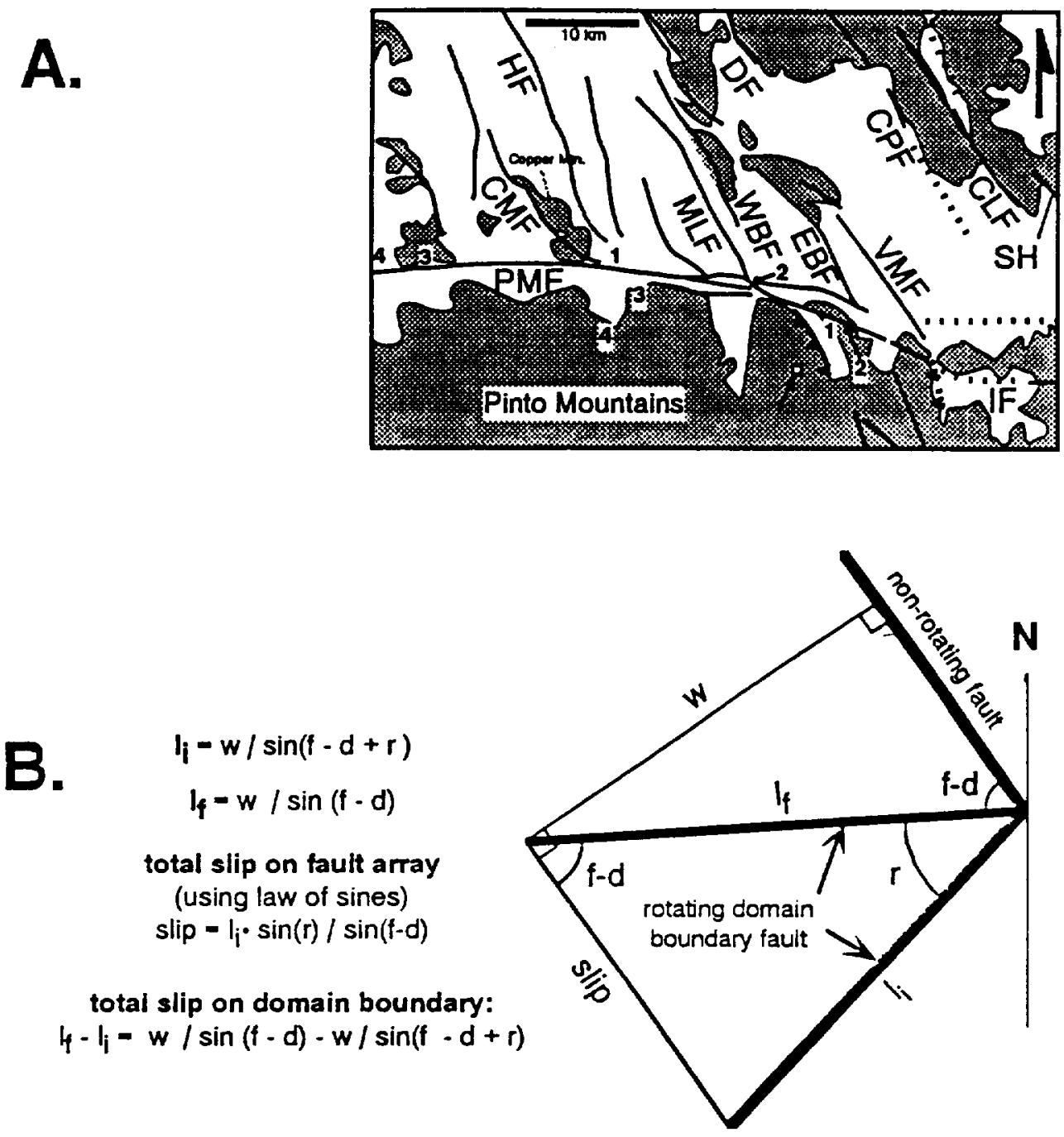

d - domain boundary strike (e. $\mathrm{g}$.

Pinto Mountains fault)

$f$ - strike of non-rotating fault set

(e. g. Mojave Desert northwesttrending faults)

$l_{f}=$ final length of intersection

between rotating and non-rotating domains

Ii - initial length of intersection

between rotating and non-rotating domains

$r=$ rotation (>0 clockwise)

$w=$ width of non-rotating fault domain

c. start

after $24^{\circ}$ of rotation
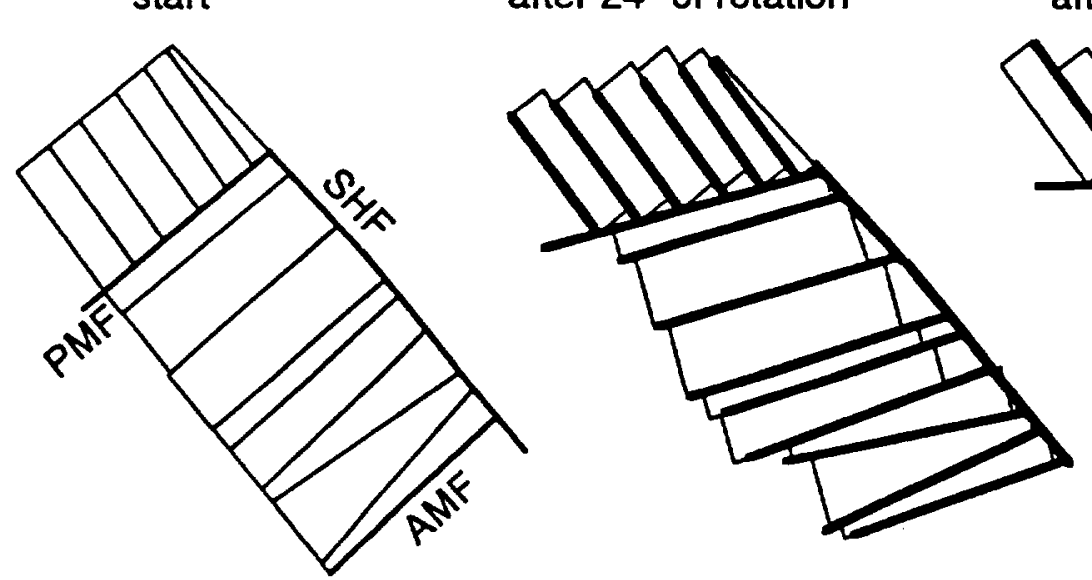

after $39^{\circ}$ of rotation

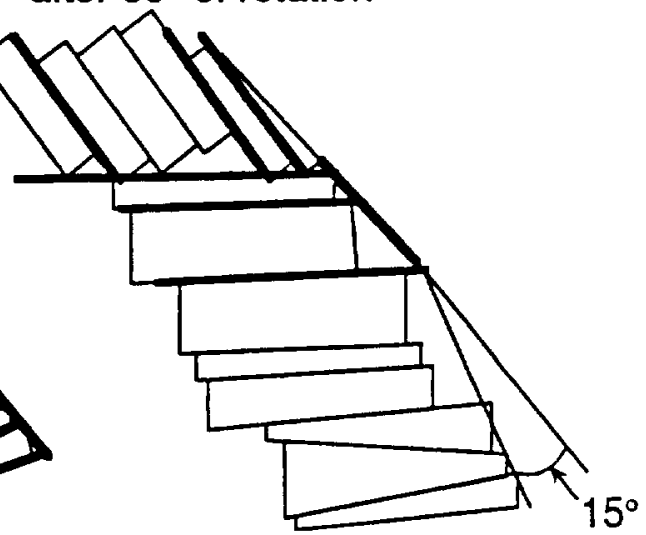

Figure 11 


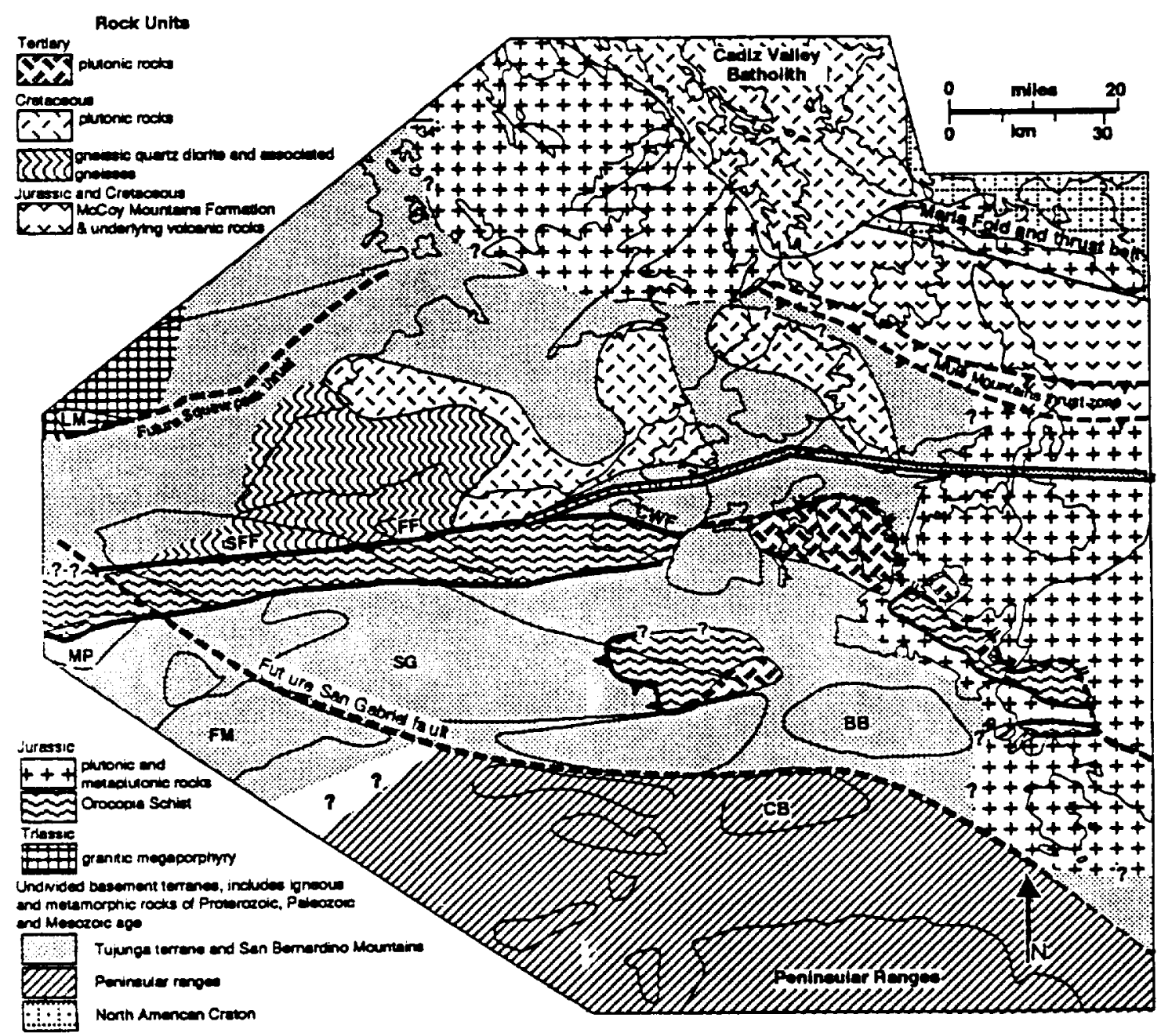

Figure 12. Sketch reconstruction of
Southeastern California, $10 \mathrm{Ma}$

S. M. Richard 9/1992 